\title{
Hepatic lipid accumulation: cause and consequence of dysregulated glucoregulatory hormones
}

\author{
Caroline E Geisler and Benjamin J Renquist
}

School of Animal and Comparative Biomedical Sciences, University of Arizona, Tucson, Arizona, USA

Correspondence should be addressed to B J Renquist

Email

bjrenquist@email.arizona. edu

\begin{abstract}
Fatty liver can be diet, endocrine, drug, virus or genetically induced. Independent of cause, hepatic lipid accumulation promotes systemic metabolic dysfunction. By acting as peroxisome proliferator-activated receptor (PPAR) ligands, hepatic non-esterified fatty acids upregulate expression of gluconeogenic, beta-oxidative, lipogenic and ketogenic genes, promoting hyperglycemia, hyperlipidemia and ketosis. The typical hormonal environment in fatty liver disease consists of hyperinsulinemia, hyperglucagonemia, hypercortisolemia, growth hormone deficiency and elevated sympathetic tone. These endocrine and metabolic changes further encourage hepatic steatosis by regulating adipose tissue lipolysis, liver lipid uptake, de novo lipogenesis (DNL), beta-oxidation, ketogenesis and lipid export. Hepatic lipid accumulation may be induced by 4 separate mechanisms: (1) increased hepatic uptake of circulating fatty acids, (2) increased hepatic de novo fatty acid synthesis, (3) decreased hepatic beta-oxidation and (4) decreased hepatic lipid export. This review will discuss the hormonal regulation of each mechanism comparing multiple physiological models of hepatic lipid accumulation. Nonalcoholic fatty liver disease (NAFLD) is typified by increased hepatic lipid uptake, synthesis, oxidation and export. Chronic hepatic lipid signaling through PPARgamma results in gene expression changes that allow concurrent activity of DNL and beta-oxidation. The importance of hepatic steatosis in driving systemic metabolic dysfunction is highlighted by the common endocrine and metabolic disturbances across many conditions that result in fatty liver. Understanding the mechanisms underlying the metabolic dysfunction that develops as a consequence of hepatic lipid accumulation is critical to identifying points of intervention in this increasingly prevalent disease state.
\end{abstract}

\author{
Key Words \\ - insulin resistance \\ - obesity \\ - nonalcoholic fatty liver \\ disease \\ - peroxisome proliferator- \\ activated receptor
}

\section{Introduction}

Fatty liver is common to a wide range of human conditions. Nonalcoholic fatty liver disease (NAFLD) is the most frequent chronic liver disease in developed countries and its increased prevalence parallels the rise in obesity, type 2 diabetes and metabolic syndrome in recent decades (Tuyama \& Chang 2012, Yki-Jarvinen 2016). NAFLD encompasses hepatic steatosis driven by factors other than excessive alcohol consumption and is estimated to affect $25 \%$ of the global population (Zhu et al. 2015). While NAFLD most commonly refers to 
fatty liver resulting from overnutrition and consumption of a western diet, NAFLD may also be induced by endocrine disorders, viral infections or side effects of pharmacological therapies.

The prevalence of alcoholic fatty liver disease (AFLD) in the general population is approximately $8 \%$ (Kotronen et al. 2010, Kim et al. 2014b). Like NAFLD, the prevalence of AFLD is expected to rise (Toshikuni et al. 2014). While both AFLD and NAFLD have similar histology and disease progression, AFLD also induces molecular and clinical changes that are attributed to high alcohol consumption, and not as a result of hepatic lipid accumulation (Toshikuni et al. 2014, Rasineni et al. 2016). Interestingly, both AFLD and NAFLD are strongly associated with metabolic syndrome and type 2 diabetes (Kotronen et al. 2010), suggesting that fatty liver, independent of origin, promotes systemic metabolic dysfunction.

The severity of fatty liver disease is directly related to classic components of the metabolic syndrome including central obesity, insulin resistance, hyperinsulinemia, hypertriglyceridemia and hyperglycemia (Bedogni et al. 2005, Wainwright \& Byrne 2016). In fact, $60-70 \%$ of type 2 diabetics and $65-85 \%$ of obese patients (BMI $\geq 30$ ) are comorbid with NAFLD (Schindhelm et al. 2007, Fabbrini et al. 2010, Chon et al. 2016). Postprandial hyperinsulinemia is present in $100 \%$ of NAFLD cases independent of diabetes status (Manchanayake et al. 2011). Furthermore, sympathetic nervous system activity and circulating norepinephrine concentrations are commonly elevated in obesity and fatty liver disease (Pratley et al. 1995, Thorp \& Schlaich 2015). Nearly all nonalcoholic steatohepatitis (NASH) patients display insulin resistance independent of body weight (Chitturi et al. 2002). In fact, peripheral insulin resistance is now considered a better predictor of hepatic injury in NAFLD than visceral adiposity or the commonly used fibrosis scoring system (Ercin et al. 2015, Rosso et al. 2016).

Dysregulated glucagon secretion and signaling is also associated with fatty liver disease. NAFLD patients both with and without type 2 diabetes display fasting hyperglucagonemia (Bernsmeier et al. 2014, Junker et al. 2016). In fact, the suppression of plasma glucagon in response to a meal or hyperglycemia is impaired or eliminated in prediabetic and diabetic individuals (Muller et al. 1970, Unger et al. 1972, Rohrer et al. 2012, Foghsgaard et al. 2016). Glucose-mediated inhibition of glucagon secretion from pancreatic alpha cells occurs indirectly and relies on paracrine signaling from insulin secreting beta cells (Le Marchand \& Piston 2010).
Loss of this paracrine inhibition in diabetes promotes hypersecretion of glucagon, and the hyperglycemia and hyperketonemia of diabetes classically thought to be a consequence of blunted insulin signaling are mediated, in part, by excess glucagon (Brand et al. 1996, Lee et al. 2011, Unger \& Cherrington 2012). Therefore, abnormal alphacell function and an increased glucagon:insulin ratio are central to the pathology of fatty liver disease.

Hepatic lipid accumulation occurs transiently as a metabolic adaptation to fasting. In this review, fasting is defined by an increase in circulating ketone bodies and hepatic glucose output attributed to continuous food deprivation. In mice, this occurs between 4 and $8 \mathrm{~h}$ of food deprivation, while in humans, this corresponds to $12-24 \mathrm{~h}$ without food intake (Katz \& Tayek 1998, Browning et al. 2012, Geisler et al. 2016). Early in a fast, hepatic glucose output is derived both from gluconeogenesis and glycogenolysis. In conjunction with a robust reduction of hepatic glycogen stores, which occurs by 12 and $40 \mathrm{~h}$ of fasting in mice and humans, respectively (Rothman et al. 1991, Geisler et al. 2016), total hepatic glucose output declines as gluconeogenic flux remains constant (Katz \& Tayek 1998). In order to meet the systemic energy demands during a fast, hormonal signals stimulate adipose tissue to release non-esterified fatty acids (NEFA) into circulation at a rate which exceeds clearance by non-hepatic tissues (Patel et al. 2002, Djurhuus et al. 2004). Additionally, depression of hepatic glycogen stores during fasting further stimulates adipose tissue lipolysis, indicating that in addition to external hormonal signals, internal liverderived signals regulate systemic energy metabolism and promote lipid mobilization (Izumida et al. 2013). To better clear circulating fatty acids, the liver upregulates expression of the hepatic fatty acid transporter Cd36 (Xu et al. 2013). In the mouse, significant accumulation of hepatic NEFAs and triglycerides occurs within 4 and $12 \mathrm{~h}$ fasting, respectively (Geisler et al. 2016). These hepatic lipids spare the oxidation of gluconeogenic amino acids and serve as substrates to generate ketones. Prolonged ( $>50 \mathrm{~h})$ fasting in humans also results in insulin resistance, which develops after the accumulation of hepatic lipids and prevents glucose clearance by non-glucose obligate tissues (Hoeks et al. 2010, Browning et al. 2012, Hanssen et al. 2015). Thus, fasting shares a metabolic profile common to hepatic lipid accumulation including systemic insulin resistance and activation of hepatic gluconeogenesis and ketogenesis.

Given that hormonal signals are integral to hepatic lipid accumulation during fasting, it may be expected that endocrine disorders commonly result in

Published by Bioscientifica Ltd 
NAFLD. Hypogonadism, polycystic ovarian syndrome, hypothyroidism, growth hormone deficiency, hypercortisolemia, hyperaldosteronism and hyperpro-lactemia all are associated with a higher prevalence of NAFLD and insulin resistance (Hazlehurst \& Tomlinson 2013, Marino \& Jornayvaz 2015). In one cohort of growth hormone-deficient patients, $77 \%$ presented with NAFLD (Nishizawa et al. 2012). Conversely, individuals with NAFLD were found to have significantly lower growth hormone levels than controls (Xu et al. 2012). Cushing's syndrome is present in $0.00025 \%$ of the general population, yet exists in $1.4 \%$ of type 2 diabetics with 3.4\% displaying hypercortisolemia (Steffensen et al. 2016). Daily hydrocortisone dose is positively associated with hepatic lipid accumulation in humans, and exogenous corticosterone treatment in rats induces hepatic steatosis (D'Souza A et al. 2012, Auer et al. 2016). Furthermore, NAFLD patients have chronic hypothalamic-pituitaryadrenal (HPA) axis hyperactivity and subclinical hypercortisolemia (Targher et al. 2006). Dysfunction of a number of hormonal systems can contribute to NAFLD pathogenesis, as correction of underlying endocrine disorders alleviates hepatic steatosis (Marino \& Jornayvaz 2015).

Hepatic steatosis in humans can also be virus or drug induced. Hepatitis B, C and HIV infection are all mechanistically linked to hepatic lipid accumulation, and hepatic steatosis occurs in $40-50 \%$ of HIV-infected patients (Lemoine et al. 2006, Macias et al. 2014, Matthews et al. 2015, Wu et al. 2016). The common HIV therapeutic, highly active antiretroviral therapy (HAART), encourages lipodystrophy and can itself induce hepatic steatosis (Vallet-Pichard et al. 2012). Cancer therapeutics including tamoxifen, irinotecan and cisplatin are additionally known to promote fatty liver (Satapathy et al. 2015, Pan et al. 2016).

In this review, we aim to compare multiple models of hepatic lipid accumulation (diet, drug, genetic and hormone induced) to better isolate the specific phenotypes that accompany hepatic steatosis. Accordingly, we will discuss how hepatic lipids function as signaling molecules and regulators of hepatic metabolic activity to potentiate systemic metabolic dysfunction. Finally, we will compare the metabolic adaptation in models with hepatic lipid accumulation resulting from (1) increased mobilization of adipose tissue lipid stores and accumulation in the liver, (2) increased hepatic de novo lipogenesis (DNL), (3) decreased hepatic beta-oxidation and ketogenesis, or (4) decreased export of lipids from the liver in very low density lipoproteins (VLDL).

\section{Hepatic lipids as signaling molecules}

Hepatic fatty acids act as endogenous ligands that activate peroxisome proliferator receptor alpha (PPARa) regulated pathways to produce metabolic products required to meet whole body nutritional demands while fasting (Kersten et al. 1999). Fatty acid binding to nuclear PPARa allows for PPARa activation and binding to the PPAR response element (PPRE) in the promoter of many genes (Ellinghaus et al. 1999, Elholm et al. 2001). During a fast, PPARa expression is increased in response to glucagon signaling and by fatty-acid-induced PPARa-mediated selfupregulation (Pineda Torra et al. 2002, Berglund et al. 2010). This increased expression ensures that PPARa availability is not limiting to the signal generated by hepatic lipid accumulation.

PPARa signaling increases transcription of target genes in gluconeogenesis (phosphoenolpyruvate carboxykinase; PEPCK, glucose 6-phosphatase; G6Pase), beta-oxidation (carnitine palmitoyltransferase 1; CPT1) and ketogenesis (hydroxy-3-methyl glutaryl CoA synthase 2; HMGCS2) (Rodriguez et al. 1994, Pineda Torra et al. 2002, Napal et al. 2005, Tachibana et al. 2005, Im et al. 2011). PPARa transcriptional activity is further enhanced by the coactivator peroxisome proliferator-activated receptor gamma coactivator 1alpha (PGC-1a) (Vega et al. 2000, Song et al. 2010). As evidence for the central role of PPARa in coordinating the hepatic adaptation to fasting, fasted PPARa null mice are hypoglycemic and fail to become ketotic (Kersten et al. 1999, Leone et al. 1999). Additionally, PPARa null mice exhibit impaired gluconeogenesis from lactate, pyruvate and glycerol (Le May et al. 2000, Xu et al. 2002, Patsouris et al. 2004). Furthermore, blunted G6Pase upregulation in fasted PPARa null mice directs glucose 6-phosphate toward glycogen synthesis rather than hepatic export (Bandsma et al. 2004). PPARa-mediated upregulation of lipid oxidative genes also encourages maximal hepatic glucose output during fasting, since acetyl-CoA serves as an ample source of carbons for oxidation in the TCA cycle, which allows for flux of gluconeogenic substrates toward gluconeogenesis and away from TCA cycle oxidation (Pettit et al. 1975, Tutwiler \& Dellevigne 1979, Chow et al. 1990, Gonzalez-Manchon et al. 1992). In response to a fast, PPARa null mice also develop more severe hepatic steatosis than controls. By encouraging flux through beta-oxidation and ketogenesis, PPARa signaling limits the hepatic accumulation of lipids (Aoyama et al. 1998, Hashimoto et al. 2000). This prevents hepatic oxidative stress that results from the generation of reactive oxygen

Published by Bioscientifica Ltd. 
species and lipid peroxidation products in response to excess hepatic lipid accumulation (Pawlak et al. 2015). Thus, under periods of food deprivation, PPARa promotes hepatic glucose and ketone production and prevents lipotoxicity.

Gluconeogenic gene expression is upregulated in response to elevated circulating NEFA (Massillon et al. 1997). Like in fasting, the elevation of gluconeogenic enzyme expression in NAFLD is dependent upon PPARa (Im et al. 2011). Hepatic PPARa expression and transcriptional activity are induced by high-fat diet feeding (Kim et al. 2004, Patsouris et al. 2006), and elevated hepatic glucose output in diabetes is a dominant factor underlying abnormal glucose homeostasis (Consoli 1992). However, diet-induced obesity does not increase hepatic glucose production or result in hyperglycemia in mice that lack PPARa (Guerre-Millo et al. 2001, Cha et al. 2007). Interestingly, the PPARa agonist-mediated increase in G6Pase and PEPCK mRNA expression is exacerbated by dexamethasone (Lemberger et al. 1996, BernalMizrachi et al. 2007), suggesting that the hypercortisolemia observed in both obesity and fasting is important in enhancing the response to PPARa signaling generated from hepatic lipid accumulation. Glucagon and glucocorticoids upregulate the expression of PGC-1a, the PPARa coactivator, and glucocorticoid-induced gluconeogenesis is dependent upon PPARa signaling (Yoon et al. 2001, Bernal-Mizrachi et al. 2007). In fact, decreased local glucocorticoid production impairs the hepatic induction of PEPCK and G6Pase during fasting and prevents dietinduced hyperglycemia (Kotelevtsev et al. 1997). Because of reduced hepatic glucose production, mice that lack PPARa maintain glucose tolerance and insulin sensitivity when challenged with high-fat diet (Guerre-Millo et al. 2001, Cha et al. 2007).

PPARa is also essential for the upregulation in flux through beta-oxidation and ketogenesis in response to diet-induced hepatic lipid accumulation. PPARa knockout reduces fasting-stimulated hepatic betaoxidation and HMGCS2 upregulation (Le May et al. 2000). Glucagon and glucocorticoids induce HMGCS2 expression (Hegardt 1999), possibly depending upon PPARa signaling. The PPARa target and major stimulator of ketone production in mice, fibroblast growth factor 21 (FGF21), is required for the increase in beta-oxidation and ketone synthesis common to fatty liver disease (Badman et al. 2007, Xu et al. 2009b, Fisher et al. 2014). However, despite a similar obesity-induced rise in FGF21 in mice and humans, FGF21, which rises only in response to an extended 7-day fast, does not appear to drive ketogenesis in the human (Dushay et al. 2010, Fisher et al. 2010, Fazeli et al. 2015).

PPARa signaling in fatty liver disease promotes lipid catabolism and ketone production. Interestingly, PPARa signaling also upregulates expression of UCP2 (Kelly et al. 1998). UCP2 separates electron transport chain activity from ATP synthesis, leading to the decline in hepatic ATP in fatty livers. Under conditions of abundant substrate availability (e.g., hepatic lipid accumulation), this uncoupling allows for continued oxidation of fatty acids beyond that required to meet cellular energy requirements (Chavin et al. 1999). In fact, despite increased TCA cycle activity, hepatic ATP depletion is a consistent finding in hepatic steatosis (Chavin et al. 1999, Koliaki \& Roden 2013, Patterson et al. 2016). In fatty liver disease, hepatic lipid accumulation, hyperglucagonemia and hypercortisolemia synergistically increase PPARa activity and upregulate gluconeogenic, beta-oxidative and ketogenic gene expression. By increasing the potential for hepatic glucose output, lipid catabolism and ketone production, PPARainduced changes in gene expression limit the lipotoxicity of hepatic lipid accumulation. In both alcohol- and methionine-choline-deficient models of hepatic lipid accumulation, elimination of PPARa signaling increases the resulting hepatic lipid accumulation (Ip et al. 2003, Li et al. 2014). Accordingly, PPARa agonist treatment in fatty liver models consistently decreases hepatic steatosis (Ide et al. 2004, Larter et al. 2012, Barbosa-da-Silva et al. 2015, Souza-Mello 2015).

Several models of fatty liver disease have reported increased expression of both PPARa and peroxisome proliferator-activated receptor gamma (PPARg) (Memon et al. 2000, Lopez-Soldado et al. 2015). PPARg expression is mainly limited to the adipocyte, but under conditions of chronic hepatic lipid accumulation, the liver expresses considerable amounts of PPARg (VidalPuig et al. 1996, Pettinelli \& Videla 2011, Schultz et al. 2013, Barbosa-da-Silva et al. 2015). Both PPARa and PPARg recognize the same fatty acids and eicosanoids ligands (Xu et al. 1999). In fact, liver fatty acid-binding protein (L-FABP), which is upregulated in diabetes and obesity, transports fatty acids into the nucleus for both PPARa and PPARy activation (Wolfrum et al. 2001, Atshaves et al. 2010). However, the metabolic influences of each differ dramatically. PPARa is integral to limiting hepatic lipid accumulation by upregulating pathways that allow for fatty acid oxidation, ketogenesis and fatty acid export (Rakhshandehroo et al. 2007), while PPARg encourages fatty acid storage by upregulating lipogenic genes including fatty acid transporters and enzymes in fatty

Published by Bioscientifica Ltd 
acid and triglyceride synthesis (Schadinger et al. 2005). However, in fatty liver disease, PPARg can also upregulate traditionally PPARa target genes (Patsouris et al. 2006, Moran-Salvador et al. 2011). Hepatic-specific PPARg knockout protects high-fat diet-fed mice from hepatic lipid accumulation, improves glucose tolerance and prevents upregulation of lipogenic, beta-oxidative and gluconeogenic genes (Moran-Salvador et al. 2011). Thus, induction of both PPARg and PPARa by hepatic lipid accumulation directs hepatic metabolic flux toward hepatic glucose and ketone production.

PPARg is a master transcriptional regulator of adipogenesis and is required for adipocyte differentiation (Takahashi et al. 2008, Hamza et al. 2009). Highfat diet feeding elevates hepatic expression of many classically adipocyte-specific genes, making fatty livers more functionally and histologically similar to adipose tissue (Pan et al. 2015). Therefore, upregulated PPARg signaling in hepatic steatosis may promote expression of an adipogenic gene profile. This suggests that while hepatocytes adapt to chronic lipid accumulation by increasing lipid oxidation and ketogenesis, hepatocytes additionally adapt by promoting long-term storage of lipids in a manner similar to adipocytes.

\section{Mechanisms of hepatic steatosis-influence of glucoregulatory hormones}

An increase in hepatic lipid content can be generated through de novo fatty acid synthesis or influx of diet or adipose-tissue-derived fatty acids, while beta-oxidation and lipoprotein secretion decrease hepatic lipid content. The typical hormonal environment in fatty liver disease is characterized by hyperinsulinemia, hyperglucagonemia, elevated sympathetic tone, hypercortisolemia and growth hormone deficiency. This hormonal milieu alters whole body lipid metabolism and can promote the progression of more severe hepatic steatosis.

\section{Adipose tissue lipolysis and hepatic lipid uptake}

When energy demand exceeds metabolic energy from the diet, NEFAs are mobilized from white adipose tissue (WAT). Insulin and catecholamines are the dominant inhibitory and stimulatory regulators, respectively, of adipose lipolysis (Fig. 1). During fasting and exercise, insulin levels are low, allowing norepinephrine, cortisol and growth hormone to synergistically stimulate lipolysis and increase systemic fatty acid availability (Marcus et al. 1994, Djurhuus et al. 2004). Similarly, hepatic lipid accumulation induces endocrine changes that dysregulate adipose tissue lipolysis, including insulin resistance, increased sympathetic tone and HPA axis activity (Pratley et al. 1995, Ward et al. 1996, Targher et al. 2006, Armstrong et al. 2014, Thorp \& Schlaich 2015). The lipolytic hormone profile along with increased adipose tissue mass results in more adipose-tissue-derived fatty acids entering circulation in obese than in normalweight individuals (Mittendorfer et al. 2009, Howe et al. 2011).

Hormonally regulated lipolysis depends on the activity of the lipolytic enzyme, hormone-sensitive lipase (HSL)

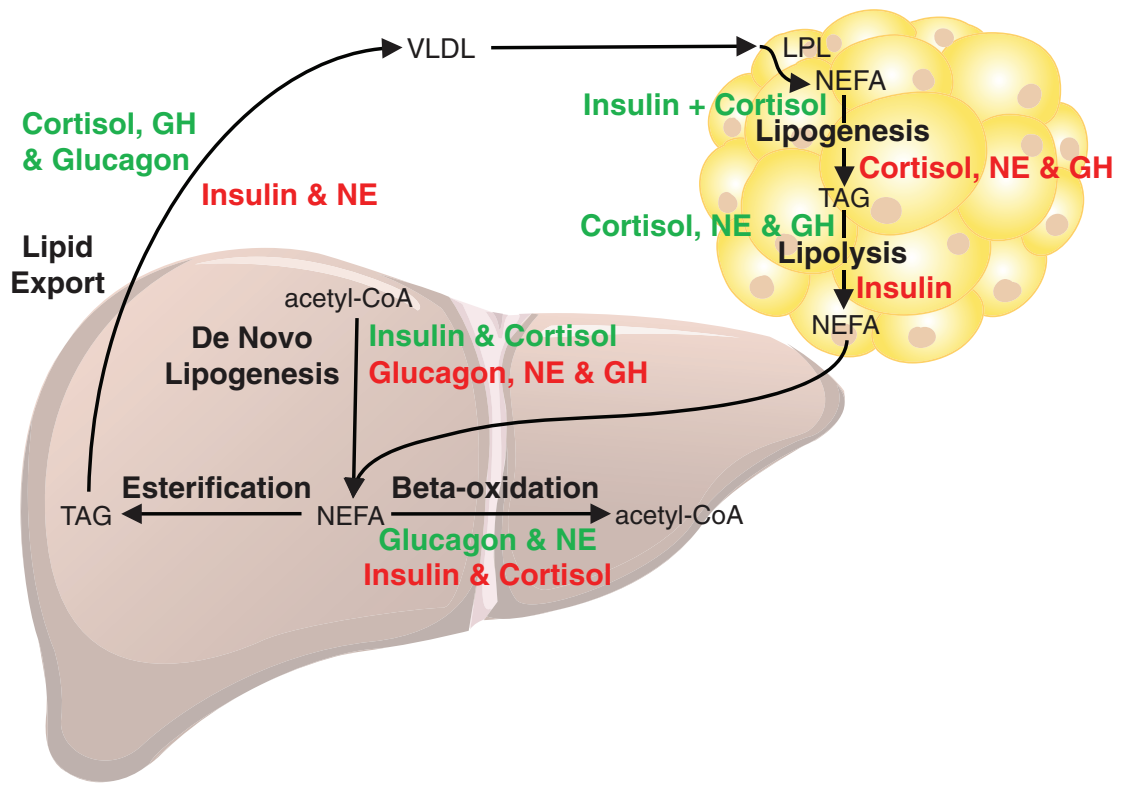

Figure 1

Effect of glucoregulatory hormones on hepatic lipid metabolism. Glucagon, cortisol, growth hormone (GH) and norepinephrine (NE) all act counter-regulatory to insulin to affect glucose homeostasis, yet have divergent effects on lipid homeostasis. Hormone signaling can induce an increase in hepatic lipid accumulation through increased adipose tissue lipolysis and hepatic lipid clearance, increased de novo lipogenesis, decreased beta-oxidation or decreased lipid export as VLDL particles. Hormones written in green text activate the indicated pathway, while hormones in red text inhibit the pathway. NEFA-Non-esterified fatty acid, TAG-Triglycerol, LPL-lipoprotein lipase. http://joe.endocrinology-journals.org DOI: $10.1530 / \mathrm{JOE}-16-0513$ (c) 2017 Society for Endocrinology Printed in Great Britain 
(Large et al. 1998). Insulin and catecholamines modulate HSL activity by decreasing and increasing adipocyte cAMP concentrations, respectively (Meijssen et al. 2001, Watt et al. 2006, Nishino et al. 2007). Sympathetic nervous system activity also stimulates cortisol release (Pacak et al. 1995), and may underlie the hypercortisolemia common in NAFLD. Cortisol differentially regulates adipose tissue metabolism depending on insulin signaling. When insulin is low, as would occur during a fast, cortisol stimulates lipolysis and inhibits lipogenesis in WAT (Djurhuus et al. 2004, Gathercole et al. 2011). Yet, in the presence of elevated insulin, cortisol synergistically stimulates lipogenesis (Fig. 1) (Ottosson et al. 1994, Wang et al. 2004). The metabolic response of adipose tissue to glucocorticoids also depends on the duration of exposure. There is not an acute lipolytic response to glucocorticoids, yet, chronically elevated glucocorticoids stimulate lipolysis in adipocytes (Xu et al. 2009a). This chronic induction of lipolysis is transcriptionally regulated, as glucocorticoids upregulate HSL expression and downregulate phosphodiesterase 3B expression, which increases HSL activity by limiting cAMP degradation (Xu et al. 2009a). Glucocorticoids also increase catecholamine-induced cAMP signaling by enhancing beta-adrenergic receptor expression, resulting in a more robust elevation in adenylyl cyclase and PKA activity (Lamberts et al. 1975, Lacasa et al. 1988). In line with the catabolic response to glucocorticoid exposure, hypercortisolemia decreases insulin-induced adipose tissue glucose clearance (Hasni Ebou et al. 2016). Moreover, chronic hypercortisolemia, obesity and NAFLD increase adipose tissue expression of 11beta-hydroxysteroid dehydrogenase type 1 (11beta-HSD1), an enzyme that catalyzes the production of cortisol from cortisone (Candia et al. 2012, Wang et al. 2015). In fact, transgenic overexpression of adipose specific 11beta-HSD1 in lean mice results in visceral obesity and insulin-resistant diabetes (Masuzaki et al. 2001). Thereby, enhanced local cortisol synthesis at adipose tissue in obesity promotes adipose tissue insulin resistance.

Excessive lipolysis and adipose tissue fatty acid release into circulation results in ectopic accumulation of lipids. Hepatic lipid accumulation is limited in mice that lack HSL and thus have muted adipose tissue lipolytic capacity. These HSL null mice have improved insulin sensitivity and systemic glucose clearance (Girousse et al. 2013, Wang et al. 2016b). Fasting and NAFLD are characterized by a rise in sympathetic activity and adipose tissue lipolysis (Migliorini et al. 1997, Grassi et al. 2005, Thorp \& Schlaich 2015). The lipolytic response to obesity depends on the adipose tissue depot, with decreased lipolytic capacity in subcutaneous adipose tissue and increased lipolysis from visceral adipose tissue (Jensen et al. 1989, Busetto et al. 1993). Adipose triglyceride lipase primarily mediates basal lipolysis, while HSL mediates catecholamine-stimulated lipolysis, and the lipolytic capacity of subcutaneous adipose tissue is largely determined by HSL expression (Large et al. 1998, Langin et al. 2005). In subcutaneous adipose tissue, obesity decreases HSL expression, limiting sensitivity to adrenergic stimulation (Langin et al. 2005, Jocken et al. 2007). Yet, in the more metabolically active visceral adipose tissue depots, sensitivity to beta3adrenoceptor-induced lipolysis is increased in obesity (Hoffstedt et al. 1996). Thus, catecholamine-stimulated lipolysis depends on the regional adipose tissue depot.

Despite increased adipose tissue lipolysis, skeletal muscle lipid clearance is decreased in obese, type 2 diabetics (Kelley \& Simoneau 1994, Turpeinen et al. 1999, Blaak et al. 2000, Blaak 2003, Goossens et al. 2016). The combination of increased fatty acid release from adipose tissue and decreased clearance by skeletal muscle results in hyperlipidemia and increased reliance on the liver to clear fatty acids (Lewis et al. 2002, Jonkers et al. 2013, Janssens et al. 2015). Hepatic expression of Cd36, a fatty acid transporter, is increased with alcohol or high-fat feeding in mice and in NAFLD (Miquilena-Colina et al. 2011, Clugston et al. 2014). Hyperinsulinemia alone can stimulate hepatic Cd36 expression, and is suggested as a primary mechanism driving hepatic lipid accumulation (Steneberg et al. 2015). Hepatic-specific knockout of Cd36 protects mice from high-fat diet-induced fatty liver and insulin resistance, supporting the hypothesis that increased hepatic lipid uptake is critical for the development of hepatic triglyceride accumulation (Wilson et al. 2016). Hepatic lipoprotein lipase (LPL) expression and activity are also increased in high-fat diet-fed mice and obese individuals, offering another mechanism for increased hepatic lipid uptake in fatty liver disease (Pardina et al. 2009, Ahn et al. 2011). These data support that dysregulated adipose tissue lipolysis and hepatic clearance are integral for the development of fatty liver in obesity.

Lipodystrophy disorders, characterized by impaired adipocyte triglyceride storage, also result in hepatic steatosis and insulin resistance (Rochford 2014). Genetic mouse models of lipodystrophy develop markedly depleted adipose stores, severe fatty liver disease and systemic insulin resistance (Saha et al. 2004, Softic et al. 2016). Due to limited adipose tissue lipid storage, patients with lipodystrophy frequently develop NAFLD and are at an increased risk for developing hypertriglyceridemia

Published by Bioscientifica Ltd. 
and diabetes (Safar Zadeh et al. 2013, Akinci et al. 2015). Antiretroviral therapy (HAART) for HIV infection commonly results in lipodystrophy. This is a consequence of adipocyte apoptosis, impaired adipogenesis and increased lipolysis, leading to hepatic lipid accumulation and insulin resistance (Nerurkar et al. 2001, Giralt et al. 2010, Goulbourne \& Vaux 2010, Kumar et al. 2015, Mandal et al. 2016). Common phenotypes between NAFLD, fasting and alcohol-induced fatty liver, and lipodystrophy patients point to the importance of hepatic lipid accumulation in driving metabolic dysregulation.

Through the multiple models of increased adipose tissue lipolysis that result in hepatic lipid accumulation (i.e. fasting, diet-induced obesity, chronic alcohol consumption and lipodystrophies), it is evident that increased fatty acid availability can drive hepatic lipid accumulation, insulin resistance and impaired glucose clearance. Moreover, hepatic lipid accumulation appears to feed forward to further increase adipose tissue lipolysis by limiting insulin sensitivity, increasing HPA axis activity and increasing catecholaminergic tone.

\section{De novo lipogenesis}

Although an influx of fatty acids from adipose tissue robustly and quickly increases hepatic lipid content, hepatic steatosis may also occur as a result of increased de novo fatty acid synthesis. Under normal physiological conditions, an elevation in circulating glucose upregulates lipogenic enzyme expression to encourage hepatic glucose clearance and storage of the carbons as fatty acids and triglycerides. Blood glucose enhances DNL through two signaling pathways. First, by increasing circulating insulin, glucose stimulates sterol response element-binding protein 1c (SREBP1c) signaling. Second, glucose can directly activate the carbohydrate response element-binding protein (ChREBP) (Iizuka et al. 2004). Both SREBP1c and ChREBP upregulate lipogenic enzymes such as acetyl-CoA carboxylase 1 (ACC1) and fatty acid synthase (FAS). Hyperinsulinemia increases SREBP1c and ChREBP expression and further promotes hepatic DNL by inhibiting FoxO1, which normally downregulates SREBP1c expression and promotes ChREBP degradation (Deng et al. 2012, Ido-Kitamura et al. 2012, Zhang et al. 2006). This coordinated response stimulates storage of excess dietary energy as triglycerides for future oxidation under energy-deplete conditions. However, chronic overconsumption of carbohydrates, a diet high in fructose, hepatic PPARg signaling, alcohol and hypercortisolemia all activate the lipogenic pathways resulting in hepatic lipid accumulation.

While a single exposure to fructose has minimal effects of hepatic lipid metabolism, a diet rich in fructose can increase flux through DNL by increasing lipogenic substrate and by promoting lipogenic gene expression. The importance of fructose as a lipogenic substrate results from the outsized role of the liver in fructose clearance. In the first pass through the liver sequesters $71 \%$ of dietary fructose, while only clearing $13 \%$ of dietary glucose (Muratoglu et al. 1986). In addition to providing the carbons necessary for fatty acid synthesis, fructose also induces signaling pathways that encourage lipogenesis. Fructose potentiates glucose-stimulated insulin secretion (Kyriazis et al. 2012), increasing insulin-mediated SREBP1c signaling in the hepatocyte. Fructose also increases SREBP1c expression and activity independent of insulin. In liver-specific insulin receptor null mice, fructose stimulates SREBP1c expression, nuclear localization and the expression of target lipogenic enzymes (Haas et al. 2012). Without altering ChREBP nuclear localization, a diet rich in fructose increases ChREBP binding to DNA nearly 4 fold (Koo et al. 2009). Interestingly, dietary fructose more robustly induces DNL in patients with fatty liver disease (Lambert et al. 2014). Thus, dietary fructose contributes to the development of NAFLD through increased DNL and NAFLD feeds forward to increase DNL from fructose.

Increased DNL is also a key factor in alcohol-induced fatty liver. Acute ethanol consumption only modestly stimulates DNL with $5 \%$ of consumed alcohol entering lipogenesis (Siler et al. 1999). However, ethanol induces transcriptional changes that encourage DNL. Ethanol inhibits hepatic 5' adenosine monophosphate-activated protein kinase (AMPK), simultaneously inhibiting betaoxidation and activating fatty acid synthesis. This decrease in AMPK is integral to the increased SREBP1C and ACC activity induced by ethanol (You et al. 2004). The SREBP1c-induced increase in ACC activity directly increases fatty acid synthesis, while suppressing fatty acid oxidation. SREBP1c also upregulates lipin-1 expression and localization to the cytosol (Hu et al. 2012). Within the cytosol, lipin-1 acts as a phosphatidate phosphatase, enzymatically converting phosphatidate to diacylglycerol and promoting triglyceride synthesis. In the nucleus, lipin-1 acts as a PPARa coactivator and facilitates the upregulation of beta-oxidative genes while suppressing lipogenic gene expression (Finck et al. 2006). By increasing lipin-1 expression and cytosolic localization, while reducing nuclear lipin-1 localization, ethanol

Published by Bioscientifica Ltd. 
simultaneously enhances triglyceride synthesis while limiting the nuclear action of lipin-1 to stimulate betaoxidation (Bi et al. 2015). Chronic alcohol consumption induces hepatic steatosis and robustly elevates expression of PPARg, inducing the adipocyte-like gene expression profile commonly observed in NAFLD (Zhang et al. 2016).

Abnormal glucocorticoid signaling is implicated in the pathology of numerous metabolic disorders, and hepatic glucocorticoid signaling stimulates hepatic lipogenesis (Krausz et al. 1981). Glucocorticoids directly upregulate lipin-1 expression (Manmontri et al. 2008), representing an intriguing mechanism driving hepatic steatosis by simultaneously decreasing lipid oxidation and increasing DNL and triglyceride esterification. By removing hairy enhancer of split 1 (Hes1), a negative regulator of PPARg expression, hepatic glucocorticoid signaling enhances PPARg expression (Revollo et al. 2013, Wu et al. 2015). In obese $\mathrm{db} / \mathrm{db}$ mice, transgenic overexpression of Hes1 prevents PPARg upregulation and corrects fatty liver (Lemke et al. 2008). Although systemic glucocorticoid concentrations are often normal in NAFLD patients, elevated adipocyte expression of 11betaHSD1 and cortisol production induced either by obesity or genetic overexpression result in hypercortisolemia in the hepatic portal circulation, exposing the liver to excess glucocorticoids (Masuzaki et al. 2001, Candia et al. 2012). Similar to adipose tissue, hepatic expression of 11beta-HSD1 and local cortisol synthesis may be more metabolically relevant than circulating cortisol levels. Interestingly, obesity is initially characterized by a decrease in hepatic 11beta-HSD1 expression in mice and humans (Ahmed et al. 2012, Candia et al. 2012). This may serve as a protective mechanism to limit local glucocorticoid production in the face of increased hepatic glucocorticoid delivery. However, progression of hepatic steatosis to NASH is accompanied by increased hepatic 11beta-HSD1 mRNA expression and activity (Ahmed et al. 2012). Hepatic 11beta-HSD1 expression has clear systemic metabolic consequences as mice that overexpress 11beta-HSD1 have excess local hepatic glucocorticoid production, increased hepatic triglyceride accumulation and overexpress FAS (Paterson et al. 2004). Despite no change in body weight or adipose tissue mass, these mice are hyperinsulinemic and insulin resistant. Conversely, hepatic-specific knockdown of 11beta-HSD1 in mice protects against western-type diet-induced hepatic steatosis by reducing hepatic lipogenesis and increasing fatty acid oxidation (Li et al. 2011). Similarly, pharmacological 11beta-HSD1 inhibition in NAFLD patients decreases hepatic lipid accumulation (Stefan et al.
2014). Thus, the elevated glucocorticoid signaling, common in fatty liver, encourages hepatic DNL.

Unlike cortisol and insulin, glucagon, norepinephrine and growth hormone inhibit hepatic DNL (Fig. 1) (Stark and Keller 1987, Cordoba-Chacon et al. 2015, Wang et al. 2016a). Growth hormone deficiency in NAFLD may contribute to hepatic steatosis by removing GH-mediated suppression of DNL. In liver-specific growth hormone knockout mice, increased hepatic DNL is driven by enhanced glycolytic flux, supplying more substrate to enter the lipogenic pathway (Cordoba-Chacon et al. 2015). Although liver PPARg is upregulated in this model, PPARg is a consequence, not a cause, of steatosis, as knockout of hepatic PPARg does not prevent development of hepatic steatosis in the absence of growth hormone signaling (Kineman et al. 2016).

Insulin-resistant NAFLD patients have markedly upregulated hepatic lipogenic gene expression and DNL flux (Schwarz et al. 2003, Eissing et al. 2013). In fact, hyperinsulinemic obese subjects have higher rates of hepatic DNL following a high-fat meal than normoinsulinemic obese or lean subjects (Schwarz et al. 2003). Increased DNL represents an important mechanism driving hepatic triglyceride accumulation in fatty liver disease.

\section{Beta-oxidation and ketogenesis}

In fatty liver disease, hepatic beta-oxidation and ketogenesis are upregulated (Sunny et al. 2010, Mannisto et al. 2015). Hepatic beta-oxidation in response to lipid accumulation prevents lipotoxicity and supports gluconeogenesis and ketogenesis. Mice that are unable to normally upregulate lipid oxidative genes during fasting have severe hepatic steatosis, do not display ketosis and are hypoglycemic (Kersten et al. 1999, Leone et al. 1999). Similarly, individuals with mitochondrial fatty acid oxidation disorders (MFAOD), conditions that affect $\sim 1$ in 10,000 people, are sensitive to fasting and high-fat diets and present with hypoketotic hypoglycemic episodes (Pollitt 1995, Rector et al. 2008).

Hepatitis C infection impairs hepatic lipid oxidation by decreasing expression of the mitochondrial trifunctional protein (MTP), an enzyme that catalyzes the last 3 steps in mitochondrial beta-oxidation (Amako et al. 2015). Mouse models with genetically or pharmacologically induced deficits in beta-oxidation develop fatty liver disease. Mice heterozygous for MTP (MTP+/-) have a 50\% reduction in hepatic

Published by Bioscientifica Ltd 
beta-oxidation, hepatic steatosis and systemic insulin resistance (Ibdah et al. 2005, Rector et al. 2013). Hepatic microRNA-107, upregulated in metabolic syndrome, inhibits the expression of the MTP alpha subunit. Exogenous miR-107 induces hepatic lipid accumulation, hyperglycemia and decreases glucose tolerance (Bhatia et al. 2016). Further, hepatic carnitine deficiency limits entry of fatty acids into the mitochondria, impairing beta-oxidative flux and inducing a more robust hepatic triglyceride accumulation as a result of high-fat diet (Du et al. 2013). Together, these models establish that limiting beta-oxidation severely exacerbates hepatic lipid accumulation. Moreover, they propose that the PPAR $\alpha$ mediated increase in beta-oxidative gene expression is key to muting hepatic lipid accumulation during a fast.

Interestingly, the hepatic lipid accumulation resulting from dietary fructose also involves PPARa signaling. Chronic ( $>2$ weeks) fructose feeding downregulates hepatic PPARa expression and activity, reducing the expression of PPARa-targeted beta-oxidative enzymes. Of note, PPARa agonists limit hepatic steatosis and improve systemic insulin sensitivity by stimulating beta-oxidation in this fructose consumption model (Nagai et al. 2002, Roglans et al. 2007). Although enhanced DNL is commonly blamed for the steatosis resulting from dietary fructose, the inhibition of beta-oxidation may be equally important. Fructose acutely inhibits CPT1 activity and beta-oxidation through a resulting increase in malonylCoA synthesis and chronically downregulates the expression of beta-oxidative genes.

Increased hepatic uptake of either diet or adiposederived fatty acids stimulates hepatic beta-oxidation (Reed et al. 1991). Like fasting-induced hepatic lipid accumulation, high-fat diet feeding elevates hepatic CPT1 activity and beta-oxidative capacity (StefanovicRacic et al. 2008, Sunny et al. 2010, Zhang et al. 2014, Geisler et al. 2016). The acetyl-CoA derived through beta-oxidation can either be oxidized through the TCA cycle or enter ketogenesis. Accordingly, diet-induced obesity increases HMGCS2 mRNA expression, increasing flux through ketogenesis (Guo et al. 2013, Darkhal et al. 2015). Finally, to regenerate NAD+ and maintain maximal beta-oxidation, obesity increases expression of UCP2 (Chavin et al. 1999). Rodents with hepatic steatosis from diets rich in fructose or sucrose also aberrantly overexpress hepatic UCP2 mRNA (Ruiz-Ramirez et al. 2011, Schultz et al. 2015). These data recommend that transcriptional changes are central to the upregulation of beta-oxidation and ketogenesis in the adaptation to hepatic lipid accumulation.
The increased ketogenesis in obesity depends on increased flux through beta-oxidation which results in increased substrate (acetyl-CoA) availability. Activity of HMGCS2, the enzyme-regulating flux through ketogenesis, is decreased by acetylation and succinylation, and increased by phosphorylation (Quant et al. 1990, Shimazu et al. 2010, Grimsrud et al. 2012). HMGCS2 is phosphorylated by PKA, a downstream glucagon signaling molecule, and hyperphosphorylation of HMGCS2 occurs in obese rodents (Grimsrud et al. 2012). Therefore, hyperglucagonemia in fatty liver increases HMGCS2 activity and ketone production. Although increased hepatic ketone synthesis is integral to the development of ketosis in obesity, insulin resistance also decreases clearance of beta-OH butyrate (Nosadini et al. 1985). In turn, beta-OH butyrate has been shown to decrease peripheral insulin-stimulated glucose uptake, and may contribute to the development of insulin resistance in fatty liver disease (Tardif et al. 2001, Yamada et al. 2010). As evidenced, the individual metabolic and hormonal perturbations common to hepatic lipid accumulation are intertwined, making it difficult to isolate the response to changes in a single pathway.

\section{The interplay of DNL and beta-oxidation}

Diminished beta-oxidative capacity resulting from genetic disorders or viral infections establishes the central role of beta-oxidative flux in limiting steatosis. Accordingly, fasting and hypercaloric diets that increase hepatic lipid accumulation induce changes in gene expression that encourage fatty acid oxidation and ketone production. However, despite enhanced lipid catabolism and ketogenic capacity resulting from increased enzyme expression and hormonal changes that promote increased enzyme activity, each of these models still develop hepatic steatosis and insulin resistance. Hepatic DNL contributes directly to the development of steatosis in NAFLD. However, the inhibition of beta-oxidative flux, an indirect response to elevated DNL may more robustly encourage steatosis.

Fatty acid flux through beta-oxidation is inhibited by hepatic DNL. The production of malonyl-CoA inhibits activity of CPT1, limiting the mitochondrial entry of fatty acids for oxidation (Morillas et al. 2002). This interaction prevents newly synthesized fatty acids from undergoing oxidation and avoids futile nutrient cycling. Malonyl-CoA production is regulated by ACC1 and ACC2, while degradation is dependent upon the activity of malonyl-CoA decarboxylase (MCD). ACC1

Published by Bioscientifica Ltd 
expression and activity increases in fatty liver disease, while ACC2 expression is independent of hepatic lipid accumulation (Yahagi et al. 2005, Kennedy et al. 2007, Kohjima et al. 2007). This increase in total ACC activity increases malonyl-CoA synthesis, hepatic malonyl-CoA concentration and flux through fatty acid synthesis (Zhao et al. 2009). The increase in hepatic malonyl-CoA would be expected to inhibit CPT1 and beta-oxidative flux. However, in fatty liver, both fatty acid synthesis and beta-oxidation can be simultaneously increased as a result of the subcellular distribution of ACC activity. ACC1 is located in the cytosol, while ACC2 is tethered to the outer mitochondrial membrane (Abu-Elheiga et al. 2000). Accordingly, ACC2 produces malonyl-CoA in close proximity to CPT1 and is therefore the enzyme more responsible for the inhibition of beta-oxidation. In fact, ACC2 deletion prevents hepatic lipid accumulation and increases fatty acid oxidation, while simultaneously preventing the diet-induced insulin resistance and glucose intolerance (Abu-Elheiga et al. 2003). The activity of ACC2 is inhibited by AMPK, a cellular energy sensor regulated by AMP, glucagon and insulin (Jeon et al. 2012). AMPK activity increases with a decrease in cellular energy. Accordingly, insulin inhibits AMPK to increase ACC2 activity and malonyl-CoA production (Witters et al. 1988, Shaw 2013, Valentine et al. 2014). This increase in malonyl-CoA production limits fatty acid oxidation. In contrast, glucagon increases AMPK activity to depress ACC2 activity and malonyl-CoA production, which encourages fatty acid oxidation (Geelen et al. 1978, Berglund et al. 2009, Cyphert et al. 2014).

In addition to altering the enzymes involved in malonyl-CoA synthesis, AMPK simultaneously alters malonyl-CoA breakdown. MCD catalyzes the conversion of malonyl-CoA to acetyl-CoA, relieving CPT1 inhibition (Dyck et al. 2000). A genetic model of hepatic MCD overexpression establishes that decreasing hepatic malonyl-CoA concentrations increases beta-oxidative flux, improves whole body insulin sensitivity and prevents hyperinsulinemia on a high-fat diet (An et al. 2004). Hepatic MCD expression is increased by PPARa agonism, representing another mechanism by which hepatic lipid-induced PPARa signaling accelerates fatty acid oxidation. (Lee et al. 2004). AMPK activates MCD (Sambandam et al. 2004). Through modulating AMPK signaling, glucagon increases MCD activity, promoting conversion of malonyl-CoA to acetyl-CoA and relieving CPT1 inhibition, while insulin inhibits MCD activity and reduces CPT1 activity (Dyck et al. 2000). Thus, as evidenced by the ACC2 knockout and MCD overexpression models, malonyl-CoA-mediated inhibition of CPT1 depresses maximal beta-oxidative capacity in fatty liver disease. However, given the subcellular distribution and divergent regulation of hepatic lipid accumulation on ACC expression, simultaneous stimulation of lipogenic and beta-oxidative flux can occur.

This concurrent flux through fatty acid synthesis and oxidation occurs normally in non-hepatic tissue as an adaptive mechanism to promote substrate utilization and increase cellular metabolic rate (Solinas et al. 2004, Mottillo et al. 2014, O'Sullivan et al. 2014). Like in fatty liver, this simultaneous induction of lipogenesis and oxidation is proposed to be dependent upon diminished ACC2-generated malonyl-CoA and submaximal CPT1 inhibition (Yu et al. 2002). In adipose tissue, PPARgdependent DNL upregulation enhances glucose clearance and utilization, allowing adipocytes to act as a glucose sink to maintain euglycemia (Marcelino et al. 2013). Increased hepatic DNL in fatty liver disease may similarly serve as a mechanism to minimize hyperglycemia, while increased beta-oxidation allows energy dissipation and protects against lipotoxicity. The upregulation of PPARg and lipogenic gene expression in response to chronic hepatic lipid accumulation drives the increase in DNL in fatty liver disease (Matsusue et al. 2003), and supports the simultaneous induction of lipogenesis and beta-oxidation. The onset of this nutrient cycling represents another mechanism by which hepatocytes adopt metabolic characteristics of adipocytes to accommodate long-term lipid accumulation.

\section{Hepatic lipid export and extrahepatic lipid clearance}

Hepatocytes distribute lipids to peripheral tissues by exporting VLDL. Impaired VLDL export limits hepatic disposal of triglycerides and induces hepatic steatosis. Chronic ethanol consumption decreases VLDL synthesis and secretion, enhancing the development of fatty liver (Simpson et al. 1990, Kharbanda et al. 2009). However, since ethanol consumption increases DNL, inhibits hepatic beta-oxidation and increases adipose tissue lipolysis, the isolated response to inhibiting VLDL secretion can be better understood in genetic models with inhibited lipoprotein synthesis and release. Inhibited lipoprotein transfer increases steatosis without decreasing insulin sensitivity. Knockout of hepatic 
microsomal triglyceride transfer protein (MTTP) in mice prevents VLDL release and induces hepatic triglyceride accumulation, but does not affect systemic or hepatic insulin sensitivity (Minehira et al. 2008). Similarly in familial hypobetalipoproteinemia (FHBL), an autosomal codominant disorder, heterozygous individuals have a $60-75 \%$ reduction in VLDL production that commonly results in fatty liver (Elias et al. 1999, Lonardo et al. 2006). Again, in FHBL individuals, there is a dissociation between hepatic steatosis and insulin resistance (Della Corte et al. 2013). In BMI-matched controls, FHBL patients had the same degree of hepatic lipid accumulation as NAFLD patients $(20 \%)$ but retained similar hepatic insulin sensitivity as subjects with low hepatic triglyceride content ( 3\%) (Amaro et al. 2010). These genetic examples propose that hepatic steatosis resulting from depressed hepatic lipid export mechanistically differs from steatosis resulting from decreased beta-oxidation, increased DNL or increased circulating lipid clearance.

Interestingly, VLDL production and release are typically amplified in patients with NAFLD and the metabolic syndrome, contributing to hypertriglyceridemia and extrahepatic lipid uptake (Shojaee-Moradie et al. 2013). Glucagon, cortisol and growth hormone stimulate hepatic VLDL secretion, while norepinephrine inhibits secretion (Fig. 1) (Elam et al. 1992, Bjornsson et al. 1994, Yamauchi et al. 1998, de Guia et al. 2015). The high circulating glucagon and cortisol concentrations in fatty liver disease may contribute to hypercholesterolemia by enhancing VLDL export. Insulin signaling inhibits hepatic VLDL release (Chirieac et al. 2002). The hepatic transcription factor forkhead box protein O6 (FoxO6) upregulates MTTP, which catalyzes the rate limiting step in VLDLtriglyceride assembly. Insulin signaling inactivates FoxO6, reducing MTTP activity and VLDL production. Hepatic insulin resistance therefore prevents FoxO6 inactivation and promotes overactive assembly of VLDL particles, while FoxO6 knockdown in obese $\mathrm{db} / \mathrm{db}$ mice ameliorates VLDL overproduction and hypertriglyceridemia (Kim et al. 2014a). Together, hyperglucagonemia, hypercortisolemia and insulin resistance encourage VLDL hypersecretion in fatty liver disease. Accordingly, while impaired hepatic VLDL release can cause hepatic steatosis, fatty liver disease is more commonly associated with enhanced VLDL secretion (Fujita et al. 2009). The hormonal environment of insulin resistance, hyperglucagonemia and hypercortisolemia in NAFLD encourages hepatic
VLDL production and release and contributes to the hyperlipidemia of obesity. Thus, although VLDL release from hepatocytes decreases steatosis, the consequent hyperlipidemia appears to exacerbate metabolic dysfunction.

\section{Conclusion}

Hepatic lipid accumulation can result from excessive lipid influx or impaired lipid efflux. In response to elevated hepatic lipid uptake, as occurs in response to fasting, high-fat diet feeding or lipodystrophies, hepatocytes activate metabolic pathways (beta-oxidation, ketogenesis and VLDL export) to minimize lipotoxicity. Still, hepatic steatosis develops when lipid influx overwhelms these protective mechanisms. In numerous models of hepatic steatosis, including overconsumption of fat, fructose or ethanol, and genetic lipodystrophy and MFAOD conditions, fatty liver is accompanied by systemic insulin resistance. Thus, independent of origin, hepatic lipid accumulation is associated with peripheral metabolic dysfunction.

Altered hepatic metabolite flux as a consequence of hepatic lipid accumulation can affect systemic insulin signaling. Elevated circulating beta-OH butyrate concentrations, a result of upregulated ketogenesis, interfere with insulin-stimulated skeletal muscle glucose uptake, while increased hepatic glucose output exacerbates hyperglycemia and further promotes hyperinsulinemia. Enhanced VLDL secretion contributes to hypertriglyceridemia and encourages extrahepatic lipid uptake, which further impairs insulin-stimulated skeletal muscle glucose uptake. Thus, metabolic activity induced by hepatic lipid accumulation contributes to the dysregulated glucose homeostasis, which occurs in fatty liver disease.

NAFLD and insulin resistance are highly linked comorbidities. Although fatty liver develops in response to a wide diversity of physiological perturbations, these perturbations result in a similar metabolic phenotype that includes insulin resistance, hyperglucagonemia, hypertriglyceridemia, hyperglycemia and hyperketonemia. Of note, mouse models that lack hepatic lipid accumulation retain insulin sensitivity during obesity (Chen et al. 2002, Franckhauser et al. 2002, Haemmerle et al. 2006, Montgomery et al. 2013). Similarly, metabolically healthy obese humans are insulin sensitive with significantly less liver fat accumulation than obese, insulin resistance individuals (Stefan et al. 2008, 
Samocha-Bonet et al. 2012). Thus, understanding the mechanisms that result in hepatic lipid accumulation and underlie the metabolic dysfunction resulting from fatty liver is critical to identifying points of intervention to treat this increasingly prevalent disease state.

\section{Declaration of Interest}

The authors declare that there is no conflict of interest that could be perceived as prejudicing the impartiality of this review.

\section{Funding}

This work was supported by the American Heart Association (grant number 15BGIA25090300); and Arizona Department of Health Services Arizona Biomedical Research Commission (grant number ADHS14-082986).

Author Contribution Statement

C G and B R wrote and edited this review.

\section{References}

Abu-Elheiga L, Brinkley WR, Zhong L, Chirala SS, Woldegiorgis G \& Wakil SJ 2000 The subcellular localization of acetyl-CoA carboxylase 2. PNAS 97 1444-1449. (doi:10.1073/pnas.97.4.1444)

Abu-Elheiga L, Oh W, Kordari P \& Wakil SJ 2003 Acetyl-CoA carboxylase 2 mutant mice are protected against obesity and diabetes induced by high-fat/high-carbohydrate diets. PNAS 100 10207-10212. (doi:10.1073/pnas.1733877100)

Ahmed A, Rabbitt E, Brady T, Brown C, Guest P, Bujalska IJ, Doig C, Newsome PN, Hubscher S, Elias E, et al. 2012 A switch in hepatic cortisol metabolism across the spectrum of non alcoholic fatty liver disease. PLoS One 7 e29531. (doi:10.1371/journal.pone.0029531)

Ahn J, Lee H, Chung CH \& Ha T 2011 High fat diet induced downregulation of microRNA-467b increased lipoprotein lipase in hepatic steatosis. Biochemical and Biophysical Research Communications 414 664-669. (doi:10.1016/j.bbrc.2011.09.120)

Akinci B, Koseoglu FD, Onay H, Yavuz S, Altay C, Simsir IY, Ozisik S, Demir L, Korkut M, Yilmaz N, et al. 2015 Acquired partial lipodystrophy is associated with increased risk for developing metabolic abnormalities. Metabolism 64 1086-1095. (doi:10.1016/j.metabol.2015.06.004)

Amako Y, Munakata T, Kohara M, Siddiqui A, Peers C \& Harris M 2015 Hepatitis $\mathrm{C}$ virus attenuates mitochondrial lipid beta-oxidation by downregulating mitochondrial trifunctional-protein expression. Journal of Virology 89 4092-4101. (doi:10.1128/JVI.01653-14)

Amaro A, Fabbrini E, Kars M, Yue P, Schechtman K, Schonfeld G \& Klein S 2010 Dissociation between intrahepatic triglyceride content and insulin resistance in familial hypobetalipoproteinemia. Gastroenterology 139 149-153. (doi:10.1053/j.gastro.2010.03.039)

An J, Muoio DM, Shiota M, Fujimoto Y, Cline GW, Shulman GI, Koves TR, Stevens R, Millington D \& Newgard CB 2004 Hepatic expression of malonyl-CoA decarboxylase reverses muscle, liver and whole-animal insulin resistance. Nature Medicine 10 268-274. (doi:10.1038/nm995)

Aoyama T, Peters JM, Iritani N, Nakajima T, Furihata K, Hashimoto T \& Gonzalez FJ 1998 Altered constitutive expression of fatty acid-metabolizing enzymes in mice lacking the peroxisome proliferator-activated receptor alpha (PPARalpha). Journal of Biological Chemistry 273 5678-5684. (doi:10.1074/jbc.273.10.5678)

Armstrong MJ, Hazlehurst JM, Hull D, Guo K, Borrows S, Yu J, Gough SC, Newsome PN \& Tomlinson JW 2014 Abdominal subcutaneous adipose tissue insulin resistance and lipolysis in patients with non-alcoholic steatohepatitis. Diabetes, Obesity and Metabolism 16 651-660. (doi:10.1111/dom.12272)

Atshaves BP, Martin GG, Hostetler HA, McIntosh AL, Kier AB \& Schroeder F 2010 Liver fatty acid-binding protein and obesity. Journal of Nutritional Biochemistry 21 1015-1032. (doi:10.1016/j.jnutbio.2010.01.005)

Auer MK, Stalla GK \& Stieg MR 2016 Investigating the role of cortisol and growth hormone in fatty liver development: fatty liver index in patients with pituitary adenomas. Pituitary 19 461-471. (doi:10.1007/ s11102-016-0726-1)

Badman MK, Pissios P, Kennedy AR, Koukos G, Flier JS \& Maratos-Flier E 2007 Hepatic fibroblast growth factor 21 is regulated by PPARalpha and is a key mediator of hepatic lipid metabolism in ketotic states. Cell Metabolism 5 426-437. (doi:10.1016/j.cmet.2007.05.002)

Bandsma RH, Van Dijk TH, Harmsel At A, Kok T, Reijngoud DJ, Staels B \& Kuipers F 2004 Hepatic de novo synthesis of glucose 6-phosphate is not affected in peroxisome proliferator-activated receptor alpha-deficient mice but is preferentially directed toward hepatic glycogen stores after a short term fast. Journal of Biological Chemistry 279 8930-8937. (doi:10.1074/jbc.M310067200)

Barbosa-da-Silva S, Souza-Mello V, Magliano DC, Marinho Tde S, Aguila MB \& Mandarim-de-Lacerda CA 2015 Singular effects of PPAR agonists on nonalcoholic fatty liver disease of diet-induced obese mice. Life Sciences 127 73-81. (doi:10.1016/j.lfs.2015.02.003)

Bedogni G, Miglioli L, Masutti F, Tiribelli C, Marchesini G \& Bellentani S 2005 Prevalence of and risk factors for nonalcoholic fatty liver disease: the Dionysos nutrition and liver study. Hepatology 42 44-52. (doi:10.1002/hep.20734)

Berglund ED, Kang L, Lee-Young RS, Hasenour CM, Lustig DG, Lynes SE, Donahue EP, Swift LL, Charron MJ \& Wasserman DH 2010 Glucagon and lipid interactions in the regulation of hepatic AMPK signaling and expression of PPARalpha and FGF21 transcripts in vivo. American Journal of Physiology: Endocrinology and Metabolism 299 E607-E614. (doi:10.1152/ajpendo.00263.2010)

Berglund ED, Lee-Young RS, Lustig DG, Lynes SE, Donahue EP, Camacho RC, Meredith ME, Magnuson MA, Charron MJ \& Wasserman DH 2009 Hepatic energy state is regulated by glucagon receptor signaling in mice. Journal of Clinical Investigation 119 2412-2422. (doi:10.1172/JCI38650)

Bernal-Mizrachi C, Xiaozhong L, Yin L, Knutsen RH, Howard MJ, Arends JJ, Desantis P, Coleman T \& Semenkovich CF 2007 An afferent vagal nerve pathway links hepatic PPARalpha activation to glucocorticoidinduced insulin resistance and hypertension. Cell Metabolism 5 91-102. (doi:10.1016/j.cmet.2006.12.010)

Bernsmeier C, Meyer-Gerspach AC, Blaser LS, Jeker L, Steinert RE, Heim MH \& Beglinger C 2014 Glucose-induced glucagon-like Peptide 1 secretion is deficient in patients with non-alcoholic fatty liver disease. PLoS One 9 e87488. (doi:10.1371/journal.pone.0087488)

Bhatia H, Pattnaik BR \& Datta M 2016 Inhibition of mitochondrial beta-oxidation by miR-107 promotes hepatic lipid accumulation and impairs glucose tolerance in vivo. International Journal of Obesity $\mathbf{4 0}$ 861-869. (doi:10.1038/ijo.2015.225)

Bi L, Jiang Z \& Zhou J 2015 The role of lipin-1 in the pathogenesis of alcoholic fatty liver. Alcohol and Alcoholism 50 146-151. (doi:10.1093/alcalc/agu102)

Bjornsson OG, Sparks JD, Sparks CE \& Gibbons GF 1994 Regulation of VLDL secretion in primary culture of rat hepatocytes: involvement of cAMP and cAMP-dependent protein kinases. European Journal of Clinical Investigation 24 137-148. (doi:10.1111/j.1365-2362.1994.tb00979.x) 
Blaak EE 2003 Fatty acid metabolism in obesity and type 2 diabetes mellitus. Proceedings of the Nutrition Society 62 753-760. (doi:10.1079/PNS2003290)

Blaak EE, Wagenmakers AJ, Glatz JF, Wolffenbuttel BH, Kemerink GJ, Langenberg CJ, Heidendal GA \& Saris WH 2000 Plasma FFA utilization and fatty acid-binding protein content are diminished in type 2 diabetic muscle. American Journal of Physiology: Endocrinology and Metabolism 279 E146-E154.

Brand CL, Jorgensen PN, Svendsen I \& Holst JJ 1996 Evidence for a major role for glucagon in regulation of plasma glucose in conscious, nondiabetic, and alloxan-induced diabetic rabbits. Diabetes 45 1076-1083. (doi:10.2337/diab.45.8.1076)

Browning JD, Baxter J, Satapati S \& Burgess SC 2012 The effect of shortterm fasting on liver and skeletal muscle lipid, glucose, and energy metabolism in healthy women and men. Journal of Lipid Research 53 577-586. (doi:10.1194/jlr.P020867)

Busetto L, Digito M, Dalla Monta P, Carraro R \& Enzi G 1993 Omental and epigastric adipose tissue lipolytic activity in human obesity. Effect of abdominal fat distribution and relationship with hyperinsulinemia. Hormone and Metabolic Research 25 365-371. (doi:10.1055/s-2007-1002121)

Candia R, Riquelme A, Baudrand R, Carvajal CA, Morales M, Solis N, Pizarro M, Escalona A, Carrasco G, Boza C, et al. 2012 Overexpression of 11beta-hydroxysteroid dehydrogenase type 1 in visceral adipose tissue and portal hypercortisolism in non-alcoholic fatty liver disease. Liver International 32 392-399.

Cha DR, Han JY, Su DM, Zhang Y, Fan X, Breyer MD \& Guan Y 2007 Peroxisome proliferator-activated receptor-alpha deficiency protects aged mice from insulin resistance induced by high-fat diet. American Journal of Nephrology 27 479-482. (doi:10.1159/000106485)

Chavin KD, Yang S, Lin HZ, Chatham J, Chacko VP, Hoek JB, WalajtysRode E, Rashid A, Chen CH, Huang CC, et al. 1999 Obesity induces expression of uncoupling protein-2 in hepatocytes and promotes liver ATP depletion. Journal of Biological Chemistry 274 5692-5700. (doi:10.1074/jbc.274.9.5692)

Chen HC, Stone SJ, Zhou P, Buhman KK \& Farese RV Jr 2002 Dissociation of obesity and impaired glucose disposal in mice overexpressing acyl coenzyme a:diacylglycerol acyltransferase 1 in white adipose tissue. Diabetes 51 3189-3195. (doi:10.2337/diabetes.51.11.3189)

Chirieac DV, Cianci J, Collins HL, Sparks JD \& Sparks CE 2002 Insulin suppression of VLDL apo B secretion is not mediated by the LDL receptor. Biochemical and Biophysical Research Communications 297 134-137. (doi:10.1016/S0006-291X(02)02140-X)

Chitturi S, Abeygunasekera S, Farrell GC, Holmes-Walker J, Hui JM, Fung C, Karim R, Lin R, Samarasinghe D, Liddle C, et al. 2002 NASH and insulin resistance: Insulin hypersecretion and specific association with the insulin resistance syndrome. Hepatology 35 373-379. (doi:10.1053/jhep.2002.30692)

Chon YE, Kim KJ, Jung KS, Kim SU, Park JY, Kimdo Y, Ahn SH, Chon CY, Chung JB, Park KH, et al. 2016 The relationship between type 2 diabetes mellitus and non-alcoholic fatty liver disease measured by controlled attenuation parameter. Yonsei Medical Journal 57 885-892. (doi:10.3349/ymj.2016.57.4.885)

Chow JC, Planck-Meyer C \& Jesse BW 1990 Gluconeogenic dependence on ketogenesis in isolated sheep hepatocytes. Journal of Dairy Science 73 683-689. (doi:10.3168/jds.S0022-0302(90)78720-6)

Clugston RD, Yuen JJ, Hu Y, Abumrad NA, Berk PD, Goldberg IJ, Blaner WS \& Huang LS 2014 CD36-deficient mice are resistant to alcoholand high-carbohydrate-induced hepatic steatosis. Journal of Lipid Research 55 239-246. (doi:10.1194/jlr.M041863)

Consoli A 1992 Role of liver in pathophysiology of NIDDM. Diabetes Care 15 430-441. (doi:10.2337/diacare.15.3.430)

Cordoba-Chacon J, Majumdar N, List EO, Diaz-Ruiz A, Frank SJ, Manzano A, Bartrons R, Puchowicz M, Kopchick JJ \& Kineman RD 2015 Growth hormone inhibits hepatic de novo lipogenesis in adult mice. Diabetes 64 3093-3103. (doi:10.2337/db15-0370)
Cyphert HA, Alonge KM, Ippagunta SM \& Hillgartner FB 2014 Glucagon stimulates hepatic FGF21 secretion through a PKA- and EPACdependent posttranscriptional mechanism. PLoS One 9 e94996. (doi:10.1371/journal.pone.0094996)

Darkhal P, Gao M, Ma Y \& Liu D 2015 Blocking high-fat diet-induced obesity, insulin resistance and fatty liver by overexpression of Il-13 gene in mice. International Journal of Obesity 39 1292-1299. (doi:10.1038/ijo.2015.52)

de Guia RM, Rose AJ, Sommerfeld A, Seibert O, Strzoda D, Zota A, Feuchter Y, Krones-Herzig A, Sijmonsma T, Kirilov M, et al. 2015 microRNA-379 couples glucocorticoid hormones to dysfunctional lipid homeostasis. EMBO Journal 34 344-360. (doi:10.15252/embj.201490464)

Della Corte C, Fintini D, Giordano U, Cappa M, Brufani C, Majo F, Mennini C \& Nobili V 2013 Fatty liver and insulin resistance in children with hypobetalipoproteinemia: the importance of aetiology. Clinical Endocrinology 79 49-54. (doi:10.1111/j.1365-2265.2012.04498.x)

Deng X, Zhang W, I OS, Williams JB, Dong Q, Park EA, Raghow R, Unterman TG \& Elam MB 2012 FoxO1 inhibits sterol regulatory element-binding protein-1c (SREBP-1c) gene expression via transcription factors Sp1 and SREBP-1c. Journal of Biological Chemistry 287 20132-20143. (doi:10.1074/jbc.M112.347211)

Djurhuus CB, Gravholt CH, Nielsen S, Pedersen SB, Moller N \& Schmitz O 2004 Additive effects of cortisol and growth hormone on regional and systemic lipolysis in humans. American Journal of Physiology: Endocrinology and Metabolism 286 E488-494. (doi:10.1152/ajpendo.00199.2003)

D’Souza AM, Beaudry JL, Szigiato AA, Trumble SJ, Snook LA, Bonen A, Giacca A \& Riddell MC 2012 Consumption of a high-fat diet rapidly exacerbates the development of fatty liver disease that occurs with chronically elevated glucocorticoids. American Journal of Physiology: Gastrointestinal and Liver Physiology 302 G850-G863. (doi:10.1152/ajpgi.00378.2011)

Du ZY, Ma T, Liaset B, Keenan AH, Araujo P, Lock EJ, Demizieux L, Degrace P, Froyland L, Kristiansen K, et al. 2013 Dietary eicosapentaenoic acid supplementation accentuates hepatic triglyceride accumulation in mice with impaired fatty acid oxidation capacity. Biochimica et Biophysica Acta 1831 291-299. (doi:10.1016/j.bbalip.2012.10.002)

Dushay J, Chui PC, Gopalakrishnan GS, Varela-Rey M, Crawley M, Fisher FM, Badman MK, Martinez-Chantar ML \& MaratosFlier E 2010 Increased fibroblast growth factor 21 in obesity and nonalcoholic fatty liver disease. Gastroenterology 139 456-463. (doi:10.1053/j.gastro.2010.04.054)

Dyck JR, Berthiaume LG, Thomas PD, Kantor PF, Barr AJ, Barr R, Singh D, Hopkins TA, Voilley N, Prentki M, et al. 2000 Characterization of rat liver malonyl-CoA decarboxylase and the study of its role in regulating fatty acid metabolism. Biochemical Journal 350 599-608. (doi:10.1042/bj3500599)

Eissing L, Scherer T, Todter K, Knippschild U, Greve JW, Buurman WA, Pinnschmidt HO, Rensen SS, Wolf AM, Bartelt A, et al. 2013 De novo lipogenesis in human fat and liver is linked to ChREBPbeta and metabolic health. Nature Communications 41528. (doi:10.1038/ncomms2537)

Elam MB, Wilcox HG, Solomon SS \& Heimberg M 1992 In vivo growth hormone treatment stimulates secretion of very low density lipoprotein by the isolated perfused rat liver. Endocrinology 131 2717-2722. (doi:10.1210/endo.131.6.1446613)

Elholm M, Dam I, Jorgensen C, Krogsdam AM, Holst D, Kratchmarova I, Gottlicher M, Gustafsson JA, Berge R, Flatmark T, et al. 2001 Acyl-CoA esters antagonize the effects of ligands on peroxisome proliferatoractivated receptor alpha conformation, DNA binding, and interaction with Co-factors. Journal of Biological Chemistry 276 21410-21416. (doi:10.1074/jbc.M101073200)

Elias N, Patterson BW \& Schonfeld G 1999 Decreased production rates of VLDL triglycerides and ApoB-100 in subjects heterozygous for familial 
hypobetalipoproteinemia. Arteriosclerosis, Thrombosis, and Vascular Biology 19 2714-2721. (doi:10.1161/01.ATV.19.11.2714)

Ellinghaus P, Wolfrum C, Assmann G, Spener F \& Seedorf U 1999 Phytanic acid activates the peroxisome proliferator-activated receptor alpha (PPARalpha) in sterol carrier protein 2-/ sterol carrier protein x-deficient mice. Journal of Biological Chemistry 274 2766-2772. (doi:10.1074/jbc.274.5.2766)

Ercin CN, Dogru T, Genc H, Celebi G, Aslan F, Gurel H, Kara M, Sertoglu E, Tapan S, Bagci S, et al. 2015 Insulin resistance but not visceral adiposity index is associated with liver fibrosis in nondiabetic subjects with nonalcoholic fatty liver disease. Metabolic Syndrome and Related Disorders 13 319-325. (doi:10.1089/met.2015.0018)

Fabbrini E, Sullivan S \& Klein S 2010 Obesity and nonalcoholic fatty liver disease: biochemical, metabolic, and clinical implications. Hepatology 51 679-689. (doi:10.1002/hep.23280)

Fazeli PK, Lun M, Kim SM, Bredella MA, Wright S, Zhang Y, Lee H, Catana C, Klibanski A, Patwari P, et al. 2015 FGF21 and the late adaptive response to starvation in humans. Journal of Clinical Investigation 125 4601-4611. (doi:10.1172/JCI83349)

Finck BN, Gropler MC, Chen Z, Leone TC, Croce MA, Harris TE, Lawrence JC Jr \& Kelly DP 2006 Lipin 1 is an inducible amplifier of the hepatic PGC-1alpha/PPARalpha regulatory pathway. Cell Metabolism 4 199-210. (doi:10.1016/j.cmet.2006.08.005)

Fisher FM, Chui PC, Antonellis PJ, Bina HA, Kharitonenkov A, Flier JS \& Maratos-Flier E 2010 Obesity is a fibroblast growth factor 21 (FGF21)resistant state. Diabetes 59 2781-2789. (doi:10.2337/db10-0193)

Fisher FM, Chui PC, Nasser IA, Popov Y, Cunniff JC, Lundasen T, Kharitonenkov A, Schuppan D, Flier JS \& Maratos-Flier E 2014 Fibroblast growth factor 21 limits lipotoxicity by promoting hepatic fatty acid activation in mice on methionine and choline-deficient diets. Gastroenterology 147 1073-1083 e1076. (doi:10.1053/j.gastro.2014.07.044)

Foghsgaard S, Andreasen C, Vedtofte L, Andersen ES, Bahne E, Strandberg C, Buhl T, Holst JJ, Svare JA, Clausen TD, et al. 2016 Nonalcoholic fatty liver disease is prevalent in women with prior gestational diabetes mellitus and independently associated with insulin resistance and waist circumference. Diabetes Care 40 109-116 (doi:10.2337/ dc16-1017)

Franckhauser S, Munoz S, Pujol A, Casellas A, Riu E, Otaegui P, Su B $\&$ Bosch F 2002 Increased fatty acid re-esterification by PEPCK overexpression in adipose tissue leads to obesity without insulin resistance. Diabetes 51 624-630. (doi:10.2337/diabetes.51.3.624)

Fujita K, Nozaki Y, Wada K, Yoneda M, Fujimoto Y, Fujitake M, Endo H, Takahashi H, Inamori M, Kobayashi N, et al. 2009 Dysfunctional very-low-density lipoprotein synthesis and release is a key factor in nonalcoholic steatohepatitis pathogenesis. Hepatology 50 772-780. (doi:10.1002/hep.23094)

Gathercole LL, Morgan SA, Bujalska IJ, Hauton D, Stewart PM \& Tomlinson JW 2011 Regulation of lipogenesis by glucocorticoids and insulin in human adipose tissue. PLoS One 6 e26223. (doi:10.1371/journal.pone.0026223)

Geelen MJ, Beynen AC, Christiansen RZ, Lepreau-Jose MJ \& Gibson DM 1978 Short-term effects of insulin and glucagon on lipid synthesis in isolated rat hepatocytes. Covariance of acetyl-CoA carboxylase activity and the rate of $3 \mathrm{H} 2 \mathrm{O}$ incorporation into fatty acids. FEBS Letters 95 326-330. (doi:10.1016/0014-5793(78)81022-9)

Geisler CE, Hepler C, Higgins MR \& Renquist BJ 2016 Hepatic adaptations to maintain metabolic homeostasis in response to fasting and refeeding in mice. Nutrition and Metabolism 13 article 62. (doi:10.1186/s12986-016-0122-x)

Giralt M, Diaz-Delfin J, Gallego-Escuredo JM, Villarroya J, Domingo P \& Villarroya F 2010 Lipotoxicity on the basis of metabolic syndrome and lipodystrophy in HIV-1-infected patients under antiretroviral treatment. Current Pharmaceutical Design 16 3371-3378. (doi:10.2174/138161210793563527)

Girousse A, Tavernier G, Valle C, Moro C, Mejhert N, Dinel AL, Houssier M, Roussel B, Besse-Patin A, Combes M, et al. 2013 Partial inhibition of adipose tissue lipolysis improves glucose metabolism and insulin sensitivity without alteration of fat mass. PLoS Biology 11 e1001485. (doi:10.1371/journal.pbio.1001485)

Gonzalez-Manchon C, Martin-Requero A, Ayuso MS \& Parrilla R 1992 Role of endogenous fatty acids in the control of hepatic gluconeogenesis. Archives of Biochemistry and Biophysics 292 95-101. (doi:10.1016/0003-9861(92)90055-2)

Goossens GH, Moors CC, Jocken JW, van der Zijl NJ, Jans A, Konings E, Diamant M \& Blaak EE 2016 Altered skeletal muscle fatty acid handling in subjects with impaired glucose tolerance as compared to impaired fasting glucose. Nutrients 8 164. (doi:10.3390/nu8030164)

Goulbourne CN \& Vaux DJ 2010 HIV protease inhibitors inhibit FACE1/ ZMPSTE24: a mechanism for acquired lipodystrophy in patients on highly active antiretroviral therapy? Biochemical Society Transactions 38 292-296. (doi:10.1042/BST0380292)

Grassi G, Dell'Oro R, Quarti-Trevano F, Scopelliti F, Seravalle G, Paleari F, Gamba PL \& Mancia G 2005 Neuroadrenergic and reflex abnormalities in patients with metabolic syndrome. Diabetologia 48 1359-1365. (doi:10.1007/s00125-005-1798-z)

Grimsrud PA, Carson JJ, Hebert AS, Hubler SL, Niemi NM, Bailey DJ, Jochem A, Stapleton DS, Keller MP, Westphall MS, et al. 2012 A quantitative map of the liver mitochondrial phosphoproteome reveals posttranslational control of ketogenesis. Cell Metabolism 16 672-683. (doi:10.1016/j.cmet.2012.10.004)

Guerre-Millo M, Rouault C, Poulain P, Andre J, Poitout V, Peters JM, Gonzalez FJ, Fruchart JC, Reach G \& Staels B 2001 PPAR-alpha-null mice are protected from high-fat diet-induced insulin resistance. Diabetes 50 2809-2814. (doi:10.2337/diabetes.50.12.2809)

Guo Y, Darshi M, Ma Y, Perkins GA, Shen Z, Haushalter KJ, Saito R, Chen A, Lee YS, Patel HH, et al. 2013 Quantitative proteomic and functional analysis of liver mitochondria from high fat diet (HFD) diabetic mice. Molecular \& Cellular Proteomics 12 3744-3758. (doi:10.1074/mcp.m113.027441)

Haas JT, Miao J, Chanda D, Wang Y, Zhao E, Haas ME, Hirschey M, Vaitheesvaran B, Farese RV, Jr., Kurland IJ, et al. 2012 Hepatic insulin signaling is required for obesity-dependent expression of SREBP-1c mRNA but not for feeding-dependent expression. Cell Metabolism 15 873-884. (doi:10.1016/j.cmet.2012.05.002)

Haemmerle G, Lass A, Zimmermann R, Gorkiewicz G, Meyer C, Rozman J, Heldmaier G, Maier R, Theussl C, Eder S, et al. 2006 Defective lipolysis and altered energy metabolism in mice lacking adipose triglyceride lipase. Science 312 734-737. (doi:10.1126/science.1123965)

Hamza MS, Pott S, Vega VB, Thomsen JS, Kandhadayar GS, Ng PW, Chiu KP, Pettersson S, Wei CL, Ruan Y, et al. 2009 De-novo identification of PPARgamma/RXR binding sites and direct targets during adipogenesis. PLoS One 4 e4907. (doi:10.1371/journal.pone.0004907)

Hanssen MJ, Wierts R, Hoeks J, Gemmink A, Brans B, Mottaghy FM, Schrauwen P \& van Marken Lichtenbelt WD 2015 Glucose uptake in human brown adipose tissue is impaired upon fasting-induced insulin resistance. Diabetologia 58 586-595. (doi:10.1007/s00125014-3465-8)

Hashimoto T, Cook WS, Qi C, Yeldandi AV, Reddy JK \& Rao MS 2000 Defect in peroxisome proliferator-activated receptor alpha-inducible fatty acid oxidation determines the severity of hepatic steatosis in response to fasting. Journal of Biological Chemistry 275 28918-28928. (doi:10.1074/jbc.M910350199)

Hasni Ebou M, Singh-Estivalet A, Launay JM, Callebert J, Tronche F, Ferre P, Gautier JF, Guillemain G, Breant B, Blondeau B, et al. 2016 Glucocorticoids Inhibit Basal and Hormone-Induced Serotonin Synthesis in Pancreatic Beta Cells. PLoS One 11 e0149343. (doi:10.1371/journal.pone.0149343)

Hazlehurst JM \& Tomlinson JW 2013 Non-alcoholic fatty liver disease in common endocrine disorders. European Journal of Endocrinology 169 R27-R37. (doi:10.1530/EJE-13-0296)

Hegardt FG 1999 Mitochondrial 3-hydroxy-3-methylglutaryl-CoA synthase: a control enzyme in ketogenesis. Biochemical Journal 338 569-582. (doi:10.1042/bj3380569) 
Hoeks J, van Herpen NA, Mensink M, Moonen-Kornips E, van Beurden D, Hesselink MK \& Schrauwen P 2010 Prolonged fasting identifies skeletal muscle mitochondrial dysfunction as consequence rather than cause of human insulin resistance. Diabetes 59 2117-2125. (doi:10.2337/db10-0519)

Hoffstedt J, Wahrenberg H, Thorne A \& Lonnqvist F 1996 The metabolic syndrome is related to beta 3-adrenoceptor sensitivity in visceral adipose tissue. Diabetologia 39 838-844. (doi:10.1007/s001250050518)

Howe HR 3rd, Heidal K, Choi MD, Kraus RM, Boyle K \& Hickner RC 2011 Increased adipose tissue lipolysis after a 2-week high-fat diet in sedentary overweight/obese men. Metabolism 60 976-981. (doi:10.1016/j.metabol.2010.09.007)

Hu M, Wang F, Li X, Rogers CQ, Liang X, Finck BN, Mitra MS, Zhang R, Mitchell DA \& You M 2012 Regulation of hepatic lipin-1 by ethanol: role of AMP-activated protein kinase/sterol regulatory element-binding protein 1 signaling in mice. Hepatology 55 437-446. (doi:10.1002/hep.24708)

Ibdah JA, Perlegas P, Zhao Y, Angdisen J, Borgerink H, Shadoan MK, Wagner JD, Matern D, Rinaldo P \& Cline JM 2005 Mice heterozygous for a defect in mitochondrial trifunctional protein develop hepatic steatosis and insulin resistance. Gastroenterology 128 1381-1390. (doi:10.1053/j.gastro.2005.02.001)

Ide T, Tsunoda M, Mochizuki T \& Murakami K 2004 Enhancement of insulin signaling through inhibition of tissue lipid accumulation by activation of peroxisome proliferator-activated receptor (PPAR) alpha in obese mice. Medical Science Monitor 10 BR388-BR395.

Ido-Kitamura Y, Sasaki T, Kobayashi M, Kim HJ, Lee YS, Kikuchi O, Yokota-Hashimoto H, Iizuka K, Accili D \& Kitamura T 2012 Hepatic FoxO1 integrates glucose utilization and lipid synthesis through regulation of Chrebp O-glycosylation. PLoS One 7 e47231. (doi:10.1371/journal.pone.0047231)

Iizuka K, Bruick RK, Liang G, Horton JD \& Uyeda K 2004 Deficiency of carbohydrate response element-binding protein (ChREBP) reduces lipogenesis as well as glycolysis. PNAS 101 7281-7286. (doi:10.1073/ pnas.0401516101)

Im SS, Kim MY, Kwon SK, Kim TH, Bae JS, Kim H, Kim KS, Oh GT \& Ahn YH 2011 Peroxisome proliferator-activated receptor \{alpha\} is responsible for the up-regulation of hepatic glucose-6-phosphatase gene expression in fasting and $\mathrm{db} / \mathrm{db}$ Mice. Journal of Biological Chemistry 286 1157-1164. (doi:10.1074/jbc.M110.157875)

Ip E, Farrell GC, Robertson G, Hall P, Kirsch R \& Leclercq I 2003 Central role of PPARalpha-dependent hepatic lipid turnover in dietary steatohepatitis in mice. Hepatology 38 123-132. (doi:10.1053/jhep.2003.50307)

Izumida Y, Yahagi N, Takeuchi Y, Nishi M, Shikama A, Takarada A, Masuda Y, Kubota M, Matsuzaka T, Nakagawa Y, et al. 2013 Glycogen shortage during fasting triggers liver-brain-adipose neurocircuitry to facilitate fat utilization. Nature Communications 42316.

Janssens S, Jonkers RA, Groen AK, Nicolay K, van Loon LJ \& Prompers JJ 2015 Effects of acute exercise on lipid content and dietary lipid uptake in liver and skeletal muscle of lean and diabetic rats. American Journal of Physiology: Endocrinology and Metabolism 309 E874-E883.

Jensen MD, Haymond MW, Rizza RA, Cryer PE \& Miles JM 1989 Influence of body fat distribution on free fatty acid metabolism in obesity. Journal of Clinical Investigation 83 1168-1173. (doi:10.1172/JCI113997)

Jeon SM, Chandel NS \& Hay N 2012 AMPK regulates NADPH homeostasis to promote tumour cell survival during energy stress. Nature $\mathbf{4 8 5}$ 661-665. (doi:10.1038/nature11066)

Jocken JW, Langin D, Smit E, Saris WH, Valle C, Hul GB, Holm C, Arner P \& Blaak EE 2007 Adipose triglyceride lipase and hormone-sensitive lipase protein expression is decreased in the obese insulin-resistant state. Journal of Clinical Endocrinology and Metabolism 92 2292-2299. (doi:10.1210/jc.2006-1318)

Jonkers RA, van Loon LJ, Nicolay K \& Prompers JJ 2013 In vivo postprandial lipid partitioning in liver and skeletal muscle in prediabetic and diabetic rats. Diabetologia 56 618-626. (doi:10.1007/s00125-012-2792-x)

Junker AE, Gluud L, Holst JJ, Knop FK \& Vilsboll T 2016 Diabetic and nondiabetic patients with nonalcoholic fatty liver disease have an impaired incretin effect and fasting hyperglucagonaemia. Journal of Internal Medicine 279 485-493. (doi:10.1111/joim.12462)

Katz J \& Tayek JA 1998 Gluconeogenesis and the Cori cycle in 12-, 20-, and 40-h-fasted humans. American Journal of Physiology 275 E537-E542.

Kelley DE \& Simoneau JA 1994 Impaired free fatty acid utilization by skeletal muscle in non-insulin-dependent diabetes mellitus. Journal of Clinical Investigation 94 2349-2356. (doi:10.1172/JCI117600)

Kelly LJ, Vicario PP, Thompson GM, Candelore MR, Doebber TW, Ventre J, Wu MS, Meurer R, Forrest MJ, Conner MW, et al. 1998 Peroxisome proliferator-activated receptors gamma and alpha mediate in vivo regulation of uncoupling protein (UCP-1, UCP-2, UCP-3) gene expression. Endocrinology $1394920-4927$. (doi:10.1210/endo.139.12.6384)

Kennedy AR, Pissios P, Otu H, Roberson R, Xue B, Asakura K, Furukawa N, Marino FE, Liu FF, Kahn BB, et al. 2007 A high-fat, ketogenic diet induces a unique metabolic state in mice. American Journal of Physiology: Endocrinology and Metabolism 292 E1724-1739. (doi:10.1152/ajpendo.00717.2006)

Kersten S, Seydoux J, Peters JM, Gonzalez FJ, Desvergne B \& Wahli W 1999 Peroxisome proliferator-activated receptor alpha mediates the adaptive response to fasting. Journal of Clinical Investigation 103 1489-1498. (doi:10.1172/JCI6223)

Kharbanda KK, Todero SL, Ward BW, Cannella JJ, 3rd \& Tuma DJ 2009 Betaine administration corrects ethanol-induced defective VLDL secretion. Molecular and Cellular Biochemistry 327 75-78. (doi:10.1007/s11010-009-0044-2)

Kim DH, Zhang T, Lee S, Calabuig-Navarro V, Yamauchi J, Piccirillo A, Fan Y, Uppala R, Goetzman E \& Dong HH 2014a FoxO6 integrates insulin signaling with MTP for regulating VLDL production in the liver. Endocrinology 155 1255-1267. (doi:10.1210/en.2013-1856)

Kim HJ, Kim JH, Choe WH, Kwon SY \& Lee CH $2014 b$ Alcoholic fatty liver disease elevates estimated coronary heart disease risk to levels comparable with those of nonalcoholic fatty liver disease in the Korean population: a cross-sectional study. Clinical and Molecular Hepatology 20 154-161. (doi:10.3350/cmh.2014.20.2.154)

Kim S, Sohn I, Ahn JI, Lee KH, Lee YS \& Lee YS 2004 Hepatic gene expression profiles in a long-term high-fat diet-induced obesity mouse model. Gene 340 99-109. (doi:10.1016/j.gene.2004.06.015)

Kineman RD, Majumdar N, Subbaiah PV \& Cordoba-Chacon J 2016 Hepatic PPARgamma is not essential for the rapid development of steatosis after loss of hepatic GH Signaling, in adult male mice. Endocrinology 157 1728-1735. (doi:10.1210/en.2015-2077)

Kohjima M, Enjoji M, Higuchi N, Kato M, Kotoh K, Yoshimoto T, Fujino T, Yada M, Yada R, Harada N, et al. 2007 Re-evaluation of fatty acid metabolism-related gene expression in nonalcoholic fatty liver disease. International Journal of Molecular Medicine 20 351-358.

Koliaki C \& Roden M 2013 Hepatic energy metabolism in human diabetes mellitus, obesity and non-alcoholic fatty liver disease. Molecular and Cellular Endocrinology 379 35-42. (doi:10.1016/j.mce.2013.06.002)

Koo HY, Miyashita M, Cho BH \& Nakamura MT 2009 Replacing dietary glucose with fructose increases ChREBP activity and SREBP-1 protein in rat liver nucleus. Biochemical and Biophysical Research Communications 390 285-289. (doi:10.1016/j.bbrc.2009.09.109)

Kotelevtsev Y, Holmes MC, Burchell A, Houston PM, Schmoll D, Jamieson P, Best R, Brown R, Edwards CR, Seckl JR, et al. 1997 11beta-Hydroxysteroid dehydrogenase type 1 knockout mice show attenuated glucocorticoid-inducible responses and resist hyperglycemia on obesity or stress. PNAS 94 14924-14929. (doi:10.1073/pnas.94.26.14924) 
Kotronen A, Yki-Jarvinen H, Mannisto S, Saarikoski L, Korpi-Hyovalti E, Oksa H, Saltevo J, Saaristo T, Sundvall J, Tuomilehto J, et al. 2010 Non-alcoholic and alcoholic fatty liver disease - two diseases of affluence associated with the metabolic syndrome and type 2 diabetes: the FIN-D2D survey. BMC Public Health 10237. (doi:10.1186/1471-2458-10-237)

Krausz Y, Bar-On H \& Shafrir E 1981 Origin and pattern of glucocorticoidinduced hyperlipidemia in rats. Dose-dependent bimodal changes in serum lipids and lipoproteins in relation to hepatic lipogenesis and tissue lipoprotein lipase activity. Biochimica et Biophysica Acta 663 69-82. (doi:10.1016/0005-2760(81)90195-8)

Kumar NS, Shashibhushan J, Malappa, Venugopal K, Vishwanatha H \& Menon M 2015 Lipodystrophy in Human Immunodeficiency Virus (HIV) Patients on Highly Active Antiretroviral Therapy (HAART). Journal of Clinical and Diagnostic Research 9 OC05-08.

Kyriazis GA, Soundarapandian MM \& Tyrberg B 2012 Sweet taste receptor signaling in beta cells mediates fructose-induced potentiation of glucose-stimulated insulin secretion. PNAS 109 E524-E532. (doi:10.1073/pnas.1115183109)

Lacasa D, Agli B \& Giudicelli Y 1988 Permissive action of glucocorticoids on catecholamine-induced lipolysis: direct 'in vitro' effects on the fat cell beta-adrenoreceptor-coupled-adenylate cyclase system. Biochemical and Biophysical Research Communications 153 489-497. (doi:10.1016/S0006-291X(88)81121-5)

Lambert JE, Ramos-Roman MA, Browning JD \& Parks EJ 2014 Increased de novo lipogenesis is a distinct characteristic of individuals with nonalcoholic fatty liver disease. Gastroenterology 146 726-735. (doi:10.1053/j.gastro.2013.11.049)

Lamberts SW, Timmermans HA, Kramer-Blankestijn M \& Birkenhager JC 1975 The mechanism of the potentiating effect of glucocorticoids on catecholamine-induced lipolysis. Metabolism 24 681-689. (doi:10.1016/0026-0495(75)90035-9)

Langin D, Dicker A, Tavernier G, Hoffstedt J, Mairal A, Ryden M, Arner E, Sicard A, Jenkins CM, Viguerie N, et al. 2005 Adipocyte lipases and defect of lipolysis in human obesity. Diabetes 54 3190-3197. (doi:10.2337/diabetes.54.11.3190)

Large V, Arner P, Reynisdottir S, Grober J, Van Harmelen V, Holm C \& Langin D 1998 Hormone-sensitive lipase expression and activity in relation to lipolysis in human fat cells. Journal of Lipid Research $\mathbf{3 9}$ 1688-1695.

Larter CZ, Yeh MM, Van Rooyen DM, Brooling J, Ghatora K \& Farrell GC 2012 Peroxisome proliferator-activated receptor-alpha agonist, Wy 14,643, improves metabolic indices, steatosis and ballooning in diabetic mice with non-alcoholic steatohepatitis. Journal of Gastroenterology and Hepatology 27 341-350. (doi:10.1111/j.1440-1746.2011.06939.x)

Le Marchand SJ \& Piston DW 2010 Glucose suppression of glucagon secretion: metabolic and calcium responses from alpha-cells in intact mouse pancreatic islets. Journal of Biological Chemistry $\mathbf{2 8 5}$ 14389-14398. (doi:10.1074/jbc.M109.069195)

Le May C, Pineau T, Bigot K, Kohl C, Girard J \& Pegorier JP 2000 Reduced hepatic fatty acid oxidation in fasting PPARalpha null mice is due to impaired mitochondrial hydroxymethylglutarylCoA synthase gene expression. FEBS Letter 475 163-166. (doi:10.1016/S0014-5793(00)01648-3)

Lee GY, Kim NH, Zhao ZS, Cha BS \& Kim YS 2004 Peroxisomalproliferator-activated receptor alpha activates transcription of the rat hepatic malonyl-CoA decarboxylase gene: a key regulation of malonyl-CoA level. Biochemical Journal 378 983-990. (doi:10.1042/bj20031565)

Lee Y, Wang MY, Du XQ, Charron MJ \& Unger RH 2011 Glucagon receptor knockout prevents insulin-deficient type 1 diabetes in mice. Diabetes 60 391-397. (doi:10.2337/db10-0426)

Lemberger T, Saladin R, Vazquez M, Assimacopoulos F, Staels B, Desvergne B, Wahli W \& Auwerx J 1996 Expression of the peroxisome proliferator-activated receptor alpha gene is stimulated by stress and follows a diurnal rhythm. Journal of Biological Chemistry 271 1764-1769. (doi:10.1074/jbc.271.3.1764)

Lemke U, Krones-Herzig A, Berriel Diaz M, Narvekar P, Ziegler A, Vegiopoulos A, Cato AC, Bohl S, Klingmuller U, Screaton RA, et al. 2008 The glucocorticoid receptor controls hepatic dyslipidemia through Hes1. Cell Metabolism 8 212-223. (doi:10.1016/j.cmet.2008.08.001)

Lemoine M, Barbu V, Girard PM, Kim M, Bastard JP, Wendum D, Paye F, Housset C, Capeau J \& Serfaty L 2006 Altered hepatic expression of SREBP-1 and PPARgamma is associated with liver injury in insulinresistant lipodystrophic HIV-infected patients. AIDS 20 387-395. (doi:10.1097/01.aids.0000206503.01536.11)

Leone TC, Weinheimer CJ \& Kelly DP 1999 A critical role for the peroxisome proliferator-activated receptor alpha (PPARalpha) in the cellular fasting response: the PPARalpha-null mouse as a model of fatty acid oxidation disorders. PNAS 96 7473-7478. (doi:10.1073/pnas.96.13.7473)

Lewis GF, Carpentier A, Adeli K \& Giacca A 2002 Disordered fat storage and mobilization in the pathogenesis of insulin resistance and type 2 diabetes. Endocrine Reviews 23 201-229. (doi:10.1210/edrv.23.2.0461)

Li G, Hernandez-Ono A, Crooke RM, Graham MJ \& Ginsberg HN 2011 Effects of antisense-mediated inhibition of 11beta-hydroxysteroid dehydrogenase type 1 on hepatic lipid metabolism. Journal of Lipid Research 52 971-981. (doi:10.1194/jlr.M013748)

Li HH, Tyburski JB, Wang YW, Strawn S, Moon BH, Kallakury BV, Gonzalez FJ \& Fornace AJ, Jr. 2014 Modulation of fatty acid and bile acid metabolism by peroxisome proliferator-activated receptor alpha protects against alcoholic liver disease. Alcoholism Clinical and Experimental Research Journal 38 1520-1531. (doi:10.1111/acer.12424)

Lonardo A, Lombardini S, Scaglioni F, Carulli L, Ricchi M, Ganazzi D, Adinolfi LE, Ruggiero G, Carulli N \& Loria P 2006 Hepatic steatosis and insulin resistance: does etiology make a difference? Journal of Hepatology 44 190-196. (doi:10.1016/j.jhep.2005.06.018)

Lopez-Soldado I, Zafra D, Duran J, Adrover A, Calbo J \& Guinovart JJ 2015 Liver glycogen reduces food intake and attenuates obesity in a high-fat diet-fed mouse model. Diabetes 64 796-807. (doi:10.2337/db14-0728)

Macias J, Gonzalez J, Tural C, Ortega-Gonzalez E, Pulido F, Rubio R, Cifuentes C, Diaz-Menendez M, Jou A, Rubio P, et al. 2014 Prevalence and factors associated with liver steatosis as measured by transient elastography with controlled attenuation parameter in HIV-infected patients. AIDS 28 1279-1287. (doi:10.1097/QAD.0000000000000248)

Manchanayake J, Chitturi S, Nolan C \& Farrell GC 2011 Postprandial hyperinsulinemia is universal in non-diabetic patients with nonalcoholic fatty liver disease. Journal of Gastroenterology and Hepatology 26 510-516. (doi:10.1111/j.1440-1746.2010.06528.x)

Mandal A, Mukherjee A, Lakshmy R, Kabra SK \& Lodha R 2016 Dyslipidemia in HIV infected children receiving highly active antiretroviral therapy. Indian Journal of Pediatrics 83 226-231. (doi:10.1007/s12098-015-1859-3)

Manmontri B, Sariahmetoglu M, Donkor J, Bou Khalil M, Sundaram M, Yao Z, Reue K, Lehner R \& Brindley DN 2008 Glucocorticoids and cyclic AMP selectively increase hepatic lipin-1 expression, and insulin acts antagonistically. Journal of Lipid Research 49 1056-1067. (doi:10.1194/jlr.M800013-JLR200)

Mannisto VT, Simonen M, Hyysalo J, Soininen P, Kangas AJ, Kaminska D, Matte AK, Venesmaa S, Kakela P, Karja V, et al. 2015 Ketone body production is differentially altered in steatosis and non-alcoholic steatohepatitis in obese humans. Liver International 35 1853-1861. (doi:10.1111/liv.12769)

Marcelino H, Veyrat-Durebex C, Summermatter S, Sarafian D, Miles-Chan J, Arsenijevic D, Zani F, Montani JP, Seydoux J, Solinas G, et al. 2013 A role for adipose tissue de novo lipogenesis in glucose homeostasis during catch-up growth: a Randle cycle favoring fat storage. Diabetes 62 362-372. (doi:10.2337/db12-0255) 
Marcus C, Bolme P, Micha-Johansson G, Margery V \& Bronnegard M 1994 Growth hormone increases the lipolytic sensitivity for catecholamines in adipocytes from healthy adults. Life Sciences 54 1335-1341. (doi:10.1016/0024-3205(94)00512-5)

Marino L \& Jornayvaz FR 2015 Endocrine causes of nonalcoholic fatty liver disease. World Journal of Gastroenterology 21 11053-11076. (doi:10.3748/wjg.v21.i39.11053)

Massillon D, Barzilai N, Hawkins M, Prus-Wertheimer D \& Rossetti L 1997 Induction of hepatic glucose-6-phosphatase gene expression by lipid infusion. Diabetes 46 153-157. (doi:10.2337/diab.46.1.153)

Masuzaki H, Paterson J, Shinyama H, Morton NM, Mullins JJ, Seckl JR \& Flier JS 2001 A transgenic model of visceral obesity and the metabolic syndrome. Science 294 2166-2170. (doi:10.1126/science.1066285)

Matsusue K, Haluzik M, Lambert G, Yim SH, Gavrilova O, Ward JM, Brewer B, Jr., Reitman ML \& Gonzalez FJ 2003 Liver-specific disruption of PPARgamma in leptin-deficient mice improves fatty liver but aggravates diabetic phenotypes. Journal of Clinical Investigation 111 737-747. (doi:10.1172/JCI200317223)

Matthews L, Kleiner DE, Chairez C, McManus M, Nettles MJ, Zemanick K, Morse CG, Benator D, Kovacs JA \& Hadigan C 2015 Pioglitazone for hepatic steatosis in HIV/Hepatitis C virus coinfection. AIDS Research and Human Retroviruses 31 961-966. (doi:10.1089/aid.2015.0093)

Meijssen S, Cabezas MC, Ballieux CG, Derksen RJ, Bilecen S \& Erkelens DW 2001 Insulin mediated inhibition of hormone sensitive lipase activity in vivo in relation to endogenous catecholamines in healthy subjects. Journal of Clinical Endocrinology and Metabolism $\mathbf{8 6}$ 4193-4197. (doi:10.1210/jcem.86.9.7794)

Memon RA, Tecott LH, Nonogaki K, Beigneux A, Moser AH, Grunfeld C \& Feingold KR 2000 Up-regulation of peroxisome proliferator-activated receptors (PPAR-alpha) and PPAR-gamma messenger ribonucleic acid expression in the liver in murine obesity: troglitazone induces expression of PPAR-gamma-responsive adipose tissue-specific genes in the liver of obese diabetic mice. Endocrinology 141 4021-4031. (doi:10.1210/endo.141.11.7771)

Migliorini RH, Garofalo MA \& Kettelhut IC 1997 Increased sympathetic activity in rat white adipose tissue during prolonged fasting. American Journal of Physiology 272 R656-R661.

Minehira K, Young SG, Villanueva CJ, Yetukuri L, Oresic M, Hellerstein MK, Farese RV, Jr., Horton JD, Preitner F, Thorens B, et al. 2008 Blocking VLDL secretion causes hepatic steatosis but does not affect peripheral lipid stores or insulin sensitivity in mice. Journal of Lipid Research 49 2038-2044. (doi:10.1194/jlr.M800248-JLR200)

Miquilena-Colina ME, Lima-Cabello E, Sanchez-Campos S, GarciaMediavilla MV, Fernandez-Bermejo M, Lozano-Rodriguez T, VargasCastrillon J, Buque X, Ochoa B, Aspichueta P, et al. 2011 Hepatic fatty acid translocase CD36 upregulation is associated with insulin resistance, hyperinsulinaemia and increased steatosis in nonalcoholic steatohepatitis and chronic hepatitis C. Gut 60 1394-1402. (doi:10.1136/gut.2010.222844)

Mittendorfer B, Magkos F, Fabbrini E, Mohammed BS \& Klein S 2009 Relationship between body fat mass and free fatty acid kinetics in men and women. Obesity 17 1872-1877. (doi:10.1038/oby.2009.224)

Montgomery MK, Hallahan NL, Brown SH, Liu M, Mitchell TW, Cooney GJ \& Turner N 2013 Mouse strain-dependent variation in obesity and glucose homeostasis in response to high-fat feeding. Diabetologia 56 1129-1139. (doi:10.1007/s00125-013-2846-8)

Moran-Salvador E, Lopez-Parra M, Garcia-Alonso V, Titos E, MartinezClemente M, Gonzalez-Periz A, Lopez-Vicario C, Barak Y, Arroyo V \& Claria J 2011 Role for PPARgamma in obesity-induced hepatic steatosis as determined by hepatocyte- and macrophagespecific conditional knockouts. FASEB Journal 25 2538-2550. (doi:10.1096/fj.10-173716)

Morillas M, Gomez-Puertas P, Rubi B, Clotet J, Arino J, Valencia A, Hegardt FG, Serra D \& Asins G 2002 Structural model of a malonylCoA-binding site of carnitine octanoyltransferase and carnitine palmitoyltransferase I: mutational analysis of a malonyl-CoA

http://joe.endocrinology-journals.org DOI: $10.1530 / J O E-16-0513$
(C) 2017 Society for Endocrinology Printed in Great Britain affinity domain. Journal of Biological Chemistry 277 11473-11480. (doi:10.1074/jbc.M111628200)

Mottillo EP, Balasubramanian P, Lee YH, Weng C, Kershaw EE \& Granneman JG 2014 Coupling of lipolysis and de novo lipogenesis in brown, beige, and white adipose tissues during chronic beta3adrenergic receptor activation. Journal of Lipid Research 55 2276-2286. (doi:10.1194/jlr.M050005)

Muller WA, Faloona GR, Aguilar-Parada E \& Unger RH 1970 Abnormal alpha-cell function in diabetes. Response to carbohydrate and protein ingestion. New England Journal of Medicine 283 109-115. (doi:10.1056/NEJM197007162830301)

Muratoglu M, Kuyumjian J \& Kalant N 1986 First-pass hepatic uptake and utilization of glucose in the rat. Biochemical Journal 233 245-248. (doi:10.1042/bj2330245)

Nagai Y, Nishio Y, Nakamura T, Maegawa H, Kikkawa R \& Kashiwagi A 2002 Amelioration of high fructose-induced metabolic derangements by activation of PPARalpha. American Journal of Physiology: Endocrinology and Metabolism 282 E1180-E1190. (doi:10.1152/ajpendo.00471.2001)

Napal L, Marrero PF \& Haro D 2005 An intronic peroxisome proliferatoractivated receptor-binding sequence mediates fatty acid induction of the human carnitine palmitoyltransferase 1A. Journal of Molecular Biology 354 751-759. (doi:10.1016/j.jmb.2005.09.097)

Nerurkar PV, Shikuma CM \& Nerurkar VR 2001 Sterol regulatory element-binding proteins and reactive oxygen species: potential role in highly-active antiretroviral therapy (HAART)associated lipodystrophy. Clinical Biochemistry 34 519-529. (doi:10.1016/S0009-9120(01)00239-9)

Nishino N, Tamori Y \& Kasuga M 2007 Insulin efficiently stores triglycerides in adipocytes by inhibiting lipolysis and repressing PGC1alpha induction. Kobe Journal of Medical Sciences 53 99-106.

Nishizawa H, Iguchi G, Murawaki A, Fukuoka H, Hayashi Y, Kaji H, Yamamoto M, Suda K, Takahashi M, Seo Y, et al. 2012 Nonalcoholic fatty liver disease in adult hypopituitary patients with GH deficiency and the impact of GH replacement therapy. European Journal of Endocrinology 167 67-74. (doi:10.1530/EJE-12-0252)

Nosadini R, Avogaro A, Trevisan R, Duner E, Marescotti C, Iori E, Cobelli C \& Toffolo G 1985 Acetoacetate and 3-hydroxybutyrate kinetics in obese and insulin-dependent diabetic humans. American Journal of Physiology 248 R611-R620.

O'Sullivan D, van der Windt GJ, Huang SC, Curtis JD, Chang CH, Buck MD, Qiu J, Smith AM, Lam WY, DiPlato LM, et al. 2014 Memory CD8(+) T cells use cell-intrinsic lipolysis to support the metabolic programming necessary for development. Immunity 41 75-88. (doi:10.1016/j.immuni.2014.06.005)

Ottosson M, Vikman-Adolfsson K, Enerback S, Olivecrona G \& Bjorntorp P 1994 The effects of cortisol on the regulation of lipoprotein lipase activity in human adipose tissue. Journal of Clinical Endocrinology and Metabolism 79 820-825.

Pacak K, Palkovits M, Kopin IJ \& Goldstein DS 1995 Stress-induced norepinephrine release in the hypothalamic paraventricular nucleus and pituitary-adrenocortical and sympathoadrenal activity: in vivo microdialysis studies. Frontiers in Neuroendocrinology 16 89-150. (doi:10.1006/frne.1995.1004)

Pan HJ, Chang HT \& Lee CH 2016 Association between tamoxifen treatment and the development of different stages of nonalcoholic fatty liver disease among breast cancer patients. Journal of the Formosan Medical Association 115 411-417. (doi:10.1016/j. jfma.2015.05.006)

Pan X, Wang P, Luo J, Wang Z, Song Y, Ye J \& Hou X 2015 Adipogenic changes of hepatocytes in a high-fat diet-induced fatty liver mice model and non-alcoholic fatty liver disease patients. Endocrine $\mathbf{4 8}$ 834-847. (doi:10.1007/s12020-014-0384-x)

Pardina E, Baena-Fustegueras JA, Llamas R, Catalan R, Galard R, Lecube A, Fort JM, Llobera M, Allende H, Vargas V, et al. 2009 Lipoprotein lipase expression in livers of morbidly obese patients 
could be responsible for liver steatosis. Obesity Surgery 19 608-616. (doi:10.1007/s11695-009-9827-5)

Patel JN, Coppack SW, Goldstein DS, Miles JM \& Eisenhofer G 2002 Norepinephrine spillover from human adipose tissue before and after a 72-hour fast. Journal of Clinical Endocrinology and Metabolism $\mathbf{8 7}$ 3373-3377. (doi:10.1210/jcem.87.7.8695)

Paterson JM, Morton NM, Fievet C, Kenyon CJ, Holmes MC, Staels B, Seckl JR \& Mullins JJ 2004 Metabolic syndrome without obesity: Hepatic overexpression of 11beta-hydroxysteroid dehydrogenase type 1 in transgenic mice. PNAS 101 7088-7093. (doi:10.1073/pnas.0305524101)

Patsouris D, Mandard S, Voshol PJ, Escher P, Tan NS, Havekes LM, Koenig W, Marz W, Tafuri S, Wahli W, et al. 2004 PPARalpha governs glycerol metabolism. Journal of Clinical Investigation 114 94-103. (doi:10.1172/JCI200420468)

Patsouris D, Reddy JK, Muller M \& Kersten S 2006 Peroxisome proliferator-activated receptor alpha mediates the effects of highfat diet on hepatic gene expression. Endocrinology 147 1508-1516. (doi:10.1210/en.2005-1132)

Patterson RE, Kalavalapalli S, Williams CM, Nautiyal M, Mathew JT, Martinez J, Reinhard MK, McDougall DJ, Rocca JR, Yost RA, et al. 2016 Lipotoxicity in steatohepatitis occurs despite an increase in tricarboxylic acid cycle activity. American Journal of Physiology: Endocrinology and Metabolism 310 E484-494. (doi:10.1152/ajpendo.00492.2015)

Pawlak M, Bauge E, Lalloyer F, Lefebvre P \& Staels B 2015 Ketone body therapy protects from lipotoxicity and acute liver failure upon pparalpha deficiency. Molecular Endocrinology 29 1134-1143. (doi:10.1210/me.2014-1383)

Pettinelli P \& Videla LA 2011 Up-regulation of PPAR-gamma mRNA expression in the liver of obese patients: an additional reinforcing lipogenic mechanism to SREBP-1c induction. Journal of Clinical Endocrinology and Metabolism 96 1424-1430. (doi:10.1210/jc.2010-2129)

Pettit FH, Pelley JW \& Reed LJ 1975 Regulation of pyruvate dehydrogenase kinase and phosphatase by acetyl-CoA/CoA and NADH/NAD ratios. Biochemical and Biophysical Research Communications 65 575-582. (doi:10.1016/S0006-291X(75)80185-9)

Pineda Torra I, Jamshidi Y, Flavell DM, Fruchart JC \& Staels B 2002 Characterization of the human PPARalpha promoter: identification of a functional nuclear receptor response element. Molecular Endocrinology 16 1013-1028.

Pollitt RJ 1995 Disorders of mitochondrial long-chain fatty acid oxidation. Journal of Inherited Metabolic Disease 18 473-490. (doi:10.1007/BF00710058)

Pratley RE, Coon PJ, Rogus EM \& Goldberg AP 1995 Effects of weight loss on norepinephrine and insulin levels in obese older men. Metabolism 44 438-444. (doi:10.1016/0026-0495(95)90049-7)

Quant PA, Tubbs PK \& Brand MD 1990 Glucagon activates mitochondrial 3-hydroxy-3-methylglutaryl-CoA synthase in vivo by decreasing the extent of succinylation of the enzyme. European Journal of Biochemistry 187 169-174. (doi:10.1111/j.1432-1033.1990.tb15291.x)

Rakhshandehroo M, Sanderson LM, Matilainen M, Stienstra R, Carlberg C, de Groot PJ, Muller M \& Kersten S 2007 Comprehensive analysis of PPARalpha-dependent regulation of hepatic lipid metabolism by expression profiling. PPAR Research 200726839. (doi:10.1155/2007/26839)

Rasineni K, Penrice DD, Natarajan SK, McNiven MA, McVicker BL, Kharbanda KK, Casey CA \& Harris EN 2016 Alcoholic vs nonalcoholic fatty liver in rats: distinct differences in endocytosis and vesicle trafficking despite similar pathology. BMC Gastroenterology 16 27. (doi:10.1186/s12876-016-0433-4)

Rector RS, Morris EM, Ridenhour S, Meers GM, Hsu FF, Turk J \& Ibdah JA 2013 Selective hepatic insulin resistance in a murine model heterozygous for a mitochondrial trifunctional protein defect. Hepatology 57 2213-2223. (doi:10.1002/hep.26285)
Rector RS, Payne RM \& Ibdah JA 2008 Mitochondrial trifunctional protein defects: clinical implications and therapeutic approaches. Advanced Drug Delivery Reviews 60 1488-1496. (doi:10.1016/j.addr.2008.04.014)

Reed DR, Tordoff MG \& Friedman MI 1991 Enhanced acceptance and metabolism of fats by rats fed a high-fat diet. American Journal of Physiology 261 R1084-R1088.

Revollo JR, Oakley RH, Lu NZ, Kadmiel M, Gandhavadi M \& Cidlowski JA 2013 HES1 is a master regulator of glucocorticoid receptor-dependent gene expression. Science Signaling 6 ra103. (doi:10.1126/scisignal.2004389)

Rochford JJ 2014 Mouse models of lipodystrophy and their significance in understanding fat regulation. Current Topics in Developmental Biology 109 53-96. (doi:10.1016/b978-0-12-397920-9.00005-6)

Rodriguez JC, Gil-Gomez G, Hegardt FG \& Haro D 1994 Peroxisome proliferator-activated receptor mediates induction of the mitochondrial 3-hydroxy-3-methylglutaryl-CoA synthase gene by fatty acids. Journal of Biological Chemistry 269 18767-18772.

Roglans N, Vila L, Farre M, Alegret M, Sanchez RM, Vazquez-Carrera M \& Laguna JC 2007 Impairment of hepatic Stat-3 activation and reduction of PPARalpha activity in fructose-fed rats. Hepatology $\mathbf{4 5}$ 778-788. (doi:10.1002/hep.21499)

Rohrer S, Menge BA, Gruber L, Deacon CF, Schmidt WE, Veldhuis JD, Holst JJ \& Meier JJ 2012 Impaired crosstalk between pulsatile insulin and glucagon secretion in prediabetic individuals. Journal of Clinical Endocrinology and Metabolism 97 E791-E795. (doi:10.1210/jc.2011-3439)

Rosso C, Mezzabotta L, Gaggini M, Salomone F, Gambino R, Marengo A, Saba F, Vanni E, Jouness RI, Saponaro C, et al. 2016 Peripheral insulin resistance predicts liver damage in nondiabetic subjects with nonalcoholic fatty liver disease. Hepatology 63 107-116. (doi:10.1002/hep.28287)

Rothman DL, Magnusson I, Katz LD, Shulman RG \& Shulman GI 1991 Quantitation of hepatic glycogenolysis and gluconeogenesis in fasting humans with 13C NMR. Science 254 573-576. (doi:10.1126/science.1948033)

Ruiz-Ramirez A, Chavez-Salgado M, Peneda-Flores JA, Zapata E, Masso F \& El-Hafidi M 2011 High-sucrose diet increases ROS generation, FFA accumulation, UCP2 level, and proton leak in liver mitochondria. American Journal of Physiology: Endocrinology and Metabolism 301 E1198-1207. (doi:10.1152/ajpendo.00631.2010)

Safar Zadeh E, Lungu AO, Cochran EK, Brown RJ, Ghany MG, Heller T, Kleiner DE \& Gorden P 2013 The liver diseases of lipodystrophy: the long-term effect of leptin treatment. Journal of Hepatology 59 131-137. (doi:10.1016/j.jhep.2013.02.007)

Saha PK, Kojima H, Martinez-Botas J, Sunehag AL \& Chan L 2004 Metabolic adaptations in the absence of perilipin: increased betaoxidation and decreased hepatic glucose production associated with peripheral insulin resistance but normal glucose tolerance in perilipin-null mice. Journal of Biological Chemistry 279 35150-35158. (doi:10.1074/jbc.M405499200)

Sambandam N, Steinmetz M, Chu A, Altarejos JY, Dyck JR \& Lopaschuk GD 2004 Malonyl-CoA decarboxylase (MCD) is differentially regulated in subcellular compartments by 5'AMPactivated protein kinase (AMPK). Studies using H9c2 cells overexpressing MCD and AMPK by adenoviral gene transfer technique. European Journal of Biochemistry 271 2831-2840. (doi:10.1111/j.1432-1033.2004.04218.x)

Samocha-Bonet D, Chisholm DJ, Tonks K, Campbell LV \& Greenfield JR 2012 Insulin-sensitive obesity in humans - a 'favorable fat' phenotype? Trends in Endocrinology and Metabolism 23 116-124. (doi:10.1016/j.tem.2011.12.005)

Satapathy SK, Kuwajima V, Nadelson J, Atiq O \& Sanyal AJ 2015 Drug-induced fatty liver disease: An overview of pathogenesis and management. Annals of hepatology 14 789-806. (doi:10.5604/16652681.1171749) 
Schadinger SE, Bucher NL, Schreiber BM \& Farmer SR 2005 PPARgamma2 regulates lipogenesis and lipid accumulation in steatotic hepatocytes. American Journal of Physiology: Endocrinology and Metabolism 288 E1195-1205. (doi:10.1152/ajpendo.00513.2004)

Schindhelm RK, Heine RJ \& Diamant M 2007 Prevalence of nonalcoholic fatty liver disease and its association with cardiovascular disease among type 2 diabetic patients. Diabetes Care 30 e94; author reply e95. (doi:10.2337/dc07-0982)

Schultz A, Barbosa-da-Silva S, Aguila MB \& Mandarim-de-Lacerda CA 2015 Differences and similarities in hepatic lipogenesis, gluconeogenesis and oxidative imbalance in mice fed diets rich in fructose or sucrose. Food \& Function 6 1684-1691. (doi:10.1039/c5fo00251f)

Schultz A, Neil D, Aguila MB \& Mandarim-de-Lacerda CA 2013 Hepatic adverse effects of fructose consumption independent of overweight/ obesity. International Journal of Molecular Sciences 14 21873-21886. (doi:10.3390/ijms141121873)

Schwarz JM, Linfoot P, Dare D \& Aghajanian K 2003 Hepatic de novo lipogenesis in normoinsulinemic and hyperinsulinemic subjects consuming high-fat, low-carbohydrate and low-fat, high-carbohydrate isoenergetic diets. American Journal of Clinical Nutrition 77 43-50.

Shaw RJ 2013 Metformin trims fats to restore insulin sensitivity. Nature Medicine 19 1570-1572. (doi:10.1038/nm.3414)

Shimazu T, Hirschey MD, Hua L, Dittenhafer-Reed KE, Schwer B, Lombard DB, Li Y, Bunkenborg J, Alt FW, Denu JM, et al. 2010 SIRT3 deacetylates mitochondrial 3-hydroxy-3-methylglutaryl CoA synthase 2 and regulates ketone body production. Cell Metabolism 12 654-661. (doi:10.1016/j.cmet.2010.11.003)

Shojaee-Moradie F, Ma Y, Lou S, Hovorka R \& Umpleby AM 2013 Prandial hypertriglyceridemia in metabolic syndrome is due to an overproduction of both chylomicron and VLDL triacylglycerol Diabetes 62 4063-4069. (doi:10.2337/db13-0935)

Siler SQ, Neese RA \& Hellerstein MK 1999 De novo lipogenesis, lipid kinetics, and whole-body lipid balances in humans after acute alcohol consumption. American Journal of Clinical Nutrition 70 928-936.

Simpson KJ, Venkatesan S, Smith GD \& Peters TJ 1990 Very-lowdensity lipoprotein-triacylglycerol (VLDL-TG) turnover in alcoholic subjects. Biochemical Society Transactions 18 1189-1191. (doi:10.1042/bst0181189)

Softic S, Boucher J, Solheim MH, Fujisaka S, Haering MF, Homan EP, Winnay J, Perez-Atayde AR \& Kahn CR 2016 Lipodystrophy due to adipose tissue-specific insulin receptor knockout results in progressive NAFLD. Diabetes 65 2187-2200. (doi:10.2337/db16-0213)

Solinas G, Summermatter S, Mainieri D, Gubler M, Pirola L, Wymann MP, Rusconi S, Montani JP, Seydoux J \& Dulloo AG 2004 The direct effect of leptin on skeletal muscle thermogenesis is mediated by substrate cycling between de novo lipogenesis and lipid oxidation. FEBS Letter 577 539-544. (doi:10.1016/j.febslet.2004.10.066)

Song S, Attia RR, Connaughton S, Niesen MI, Ness GC, Elam MB, Hori RT, Cook GA \& Park EA 2010 Peroxisome proliferator activated receptor alpha (PPARalpha) and PPAR gamma coactivator (PGC-1alpha) induce carnitine palmitoyltransferase IA (CPT-1A) via independent gene elements. Molecular and Cellular Endocrinology 325 54-63. (doi:10.1016/j.mce.2010.05.019)

Souza-Mello V 2015 Peroxisome proliferator-activated receptors as targets to treat non-alcoholic fatty liver disease. World Journal of Hepatology 7 1012-1019. (doi:10.4254/wjh.v7.i8.1012)

Stark B \& Keller U 1987 Alpha 1-adrenergic stimulation of ketogenesis and fatty acid oxidation is associated with inhibition of lipogenesis in rat hepatocytes. Experientia 43 1104-1106. (doi:10.1007/bf01956049)

Stefan N, Kantartzis K, Machann J, Schick F, Thamer C, Rittig K, Balletshofer B, Machicao F, Fritsche A \& Haring HU 2008 Identification and characterization of metabolically benign obesity in humans. Archives of Internal Medicine 168 1609-1616. (doi:10.1001/archinte.168.15.1609)
Stefan N, Ramsauer M, Jordan P, Nowotny B, Kantartzis K, Machann J, Hwang JH, Nowotny P, Kahl S, Harreiter J, et al. 2014 Inhibition of 11beta-HSD1 with RO5093151 for non-alcoholic fatty liver disease: a multicentre, randomised, double-blind, placebocontrolled trial. Lancet Diabetes \& Endocrinology 2 406-416. (doi:10.1016/s2213-8587(13)70170-0)

Stefanovic-Racic M, Perdomo G, Mantell BS, Sipula IJ, Brown NF \& O'Doherty RM 2008 A moderate increase in carnitine palmitoyltransferase 1a activity is sufficient to substantially reduce hepatic triglyceride levels. American Journal of Physiology: Endocrinology and Metabolism 294 E969-E977. (doi:10.1152/ajpendo.00497.2007)

Steffensen C, Pereira AM, Dekkers OM \& Jorgensen JO 2016 DIAGNOSIS OF ENDOCRINE DISEASE: Prevalence of hypercortisolism in Type 2 Diabetes patients: a systematic review and meta-analysis. European Journal of Endocrinology 175 R247-R253. (doi:10.1530/EJE-16-0434)

Steneberg P, Sykaras AG, Backlund F, Straseviciene J, Soderstrom I \& Edlund H 2015 Hyperinsulinemia enhances hepatic expression of the fatty acid transporter Cd36 and provokes hepatosteatosis and hepatic insulin resistance. Journal of Biological Chemistry 290 19034-19043. (doi:10.1074/jbc.M115.640292)

Sunny NE, Satapati S, Fu X, He T, Mehdibeigi R, Spring-Robinson C, Duarte J, Potthoff MJ, Browning JD \& Burgess SC 2010 Progressive adaptation of hepatic ketogenesis in mice fed a high-fat diet. American Journal of Physiology: Endocrinology and Metabolism 298 E1226-E1235. (doi:10.1152/ajpendo.00033.2010)

Tachibana K, Kobayashi Y, Tanaka T, Tagami M, Sugiyama A, Katayama T, Ueda C, Yamasaki D, Ishimoto K, Sumitomo M, et al. 2005 Gene expression profiling of potential peroxisome proliferator-activated receptor (PPAR) target genes in human hepatoblastoma cell lines inducibly expressing different PPAR isoforms. Nuclear Receptor 33. (doi:10.1186/1478-1336-3-3)

Takahashi Y, Ohoka N, Hayashi H \& Sato R 2008 TRB3 suppresses adipocyte differentiation by negatively regulating PPARgamma transcriptional activity. Journal of Lipid Research 49 880-892. (doi:10.1194/jlr.M700545-JLR200)

Tardif A, Julien N, Pelletier A, Thibault G, Srivastava AK, Chiasson JL \& Coderre L 2001 Chronic exposure to beta-hydroxybutyrate impairs insulin action in primary cultures of adult cardiomyocytes. American Journal of Physiology: Endocrinology and Metabolism 281 E1205-E1212.

Targher G, Bertolini L, Rodella S, Zoppini G, Zenari L \& Falezza G 2006 Associations between liver histology and cortisol secretion in subjects with nonalcoholic fatty liver disease. Clinical Endocrinology 64 337-341. (doi:10.1111/j.1365-2265.2006.02466.x)

Thorp AA \& Schlaich MP 2015 Relevance of sympathetic nervous system activation in obesity and metabolic syndrome. Journal of Diabetes Research 2015341583.

Toshikuni N, Tsutsumi M \& Arisawa T 2014 Clinical differences between alcoholic liver disease and nonalcoholic fatty liver disease. World Journal of Gastroenterology 20 8393-8406. (doi:10.3748/wjg.v20.i26.8393)

Turpeinen AK, Takala TO, Nuutila P, Axelin T, Luotolahti M, Haaparanta M, Bergman J, Hamalainen H, Iida H, Maki M, et al. 1999 Impaired free fatty acid uptake in skeletal muscle but not in myocardium in patients with impaired glucose tolerance: studies with PET and 14(R,S)-[18F]fluoro-6-thia-heptadecanoic acid. Diabetes 48 1245-1250. (doi:10.2337/diabetes.48.6.1245)

Tutwiler GF \& Dellevigne P 1979 Action of the oral hypoglycemic agent 2-tetradecylglycidic acid on hepatic fatty acid oxidation and gluconeogenesis. Journal of Biological Chemistry $2542935-2941$.

Tuyama AC \& Chang CY 2012 Non-alcoholic fatty liver disease. Journal of Diabetes 4 266-280. (doi:10.1111/j.1753-0407.2012.00204.x)

Unger RH \& Cherrington AD 2012 Glucagonocentric restructuring of diabetes: a pathophysiologic and therapeutic makeover. Journal of Clinical Investigation 122 4-12. (doi:10.1172/JCI60016)

Unger RH, Madison LL \& Muller WA 1972 Abnormal alpha cell function in diabetics response to insulin. Diabetes 21 301-307. (doi:10.2337/diab.21.5.301) 
Valentine RJ, Coughlan KA, Ruderman NB \& Saha AK 2014 Insulin inhibits AMPK activity and phosphorylates AMPK Ser(4)(8)(5)/(4) (9)(1) through Akt in hepatocytes, myotubes and incubated rat skeletal muscle. Archives of Biochemistry and Biophysics 562 62-69. (doi:10.1016/j.abb.2014.08.013)

Vallet-Pichard A, Mallet V \& Pol S 2012 Nonalcoholic fatty liver disease and HIV infection. Seminars in Liver Disease 32 158-166. (doi:10.1055/s-0032-1316471)

Vega RB, Huss JM \& Kelly DP 2000 The coactivator PGC-1 cooperates with peroxisome proliferator-activated receptor alpha in transcriptional control of nuclear genes encoding mitochondrial fatty acid oxidation enzymes. Molecular and Cellular Biology 20 1868-1876. (doi:10.1128/MCB.20.5.1868-1876.2000)

Vidal-Puig A, Jimenez-Linan M, Lowell BB, Hamann A, Hu E, Spiegelman B, Flier JS \& Moller DE 1996 Regulation of PPAR gamma gene expression by nutrition and obesity in rodents. Journal of Clinical Investigation 97 2553-2561. (doi:10.1172/JCI118703)

Wainwright P \& Byrne CD 2016 Bidirectional relationships and disconnects between NAFLD and features of the metabolic syndrome. International Journal of Molecular Sciences 17 367. (doi:10.3390/ ijms17030367)

Wang H, Zhao M, Sud N, Christian P, Shen J, Song Y, Pashaj A, Zhang K, Carr T \& Su Q 2016a Glucagon regulates hepatic lipid metabolism via cAMP and Insig-2 signaling: implication for the pathogenesis of hypertriglyceridemia and hepatic steatosis. Scientific Reports 632246. (doi:10.1038/srep32246)

Wang L, Zhang B, Huang F, Liu B \& Xie Y 2016 $b$ Curcumin inhibits lipolysis via suppression of ER stress in adipose tissue and prevents hepatic insulin resistance. Journal of Lipid Research 57 1243-1255. (doi:10.1194/jlr.M067397)

Wang Y, Jones Voy B, Urs S, Kim S, Soltani-Bejnood M, Quigley N, Heo YR, Standridge M, Andersen B, Dhar M, et al. 2004 The human fatty acid synthase gene and de novo lipogenesis are coordinately regulated in human adipose tissue. Journal of Nutrition 134 1032-1038.

Wang Y, Yan C, Liu L, Wang W, Du H, Fan W, Lutfy K, Jiang M, Friedman TC \& Liu Y 2015 11beta-Hydroxysteroid dehydrogenase type 1 shRNA ameliorates glucocorticoid-induced insulin resistance and lipolysis in mouse abdominal adipose tissue. American Journal of Physiology: Endocrinology and Metabolism 308 E84-E95. (doi:10.1152/ajpendo.00205.2014)

Ward KD, Sparrow D, Landsberg L, Young JB, Vokonas PS \& Weiss ST 1996 Influence of insulin, sympathetic nervous system activity, and obesity on blood pressure: the Normative Aging Study. Journal of Hypertension 14 301-308. (doi:10.1097/00004872-199603000-00005)

Watt MJ, Holmes AG, Pinnamaneni SK, Garnham AP, Steinberg GR, Kemp BE \& Febbraio MA 2006 Regulation of HSL serine phosphorylation in skeletal muscle and adipose tissue. American Journal of Physiology: Endocrinology and Metabolism 290 E500-508. (doi:10.1152/ajpendo.00361.2005)

Wilson CG, Tran JL, Erion DM, Vera NB, Febbraio M \& Weiss EJ 2016 Hepatocyte-specific disruption of CD36 attenuates fatty liver and improves insulin sensitivity in HFD-fed mice. Endocrinology $\mathbf{1 5 7}$ 570-585. (doi:10.1210/en.2015-1866)

Witters LA, Watts TD, Daniels DL \& Evans JL 1988 Insulin stimulates the dephosphorylation and activation of acetyl-CoA carboxylase. PNAS 85 5473-5477. (doi:10.1073/pnas.85.15.5473)

Wolfrum C, Borrmann CM, Borchers T \& Spener F 2001 Fatty acids and hypolipidemic drugs regulate peroxisome proliferator-activated receptors alpha - and gamma-mediated gene expression via liver fatty acid binding protein: a signaling path to the nucleus. PNAS 98 2323-2328. (doi:10.1073/pnas.051619898)

Wu C, Jia Y, Lee JH, Kim Y, Sekharan S, Batista VS \& Lee SJ 2015 Activation of OR1A1 suppresses PPAR-gamma expression by inducing HES-1 in cultured hepatocytes. International Journal of Biochemistry \& Cell Biology 64 75-80. (doi:10.1016/j.biocel.2015.03.008)
Wu YL, Peng XE, Zhu YB, Yan XL, Chen WN \& Lin X 2016 Hepatitis B virus $\mathrm{X}$ protein induces hepatic steatosis by enhancing the expression of liver fatty acid binding protein. Journal of Virology 90 1729-1740. (doi:10.1128/JVI.02604-15)

Xu C, He J, Jiang H, Zu L, Zhai W, Pu S \& Xu G 2009a Direct effect of glucocorticoids on lipolysis in adipocytes. Molecular Endocrinology 23 1161-1170. (doi:10.1210/me.2008-0464)

Xu HE, Lambert MH, Montana VG, Parks DJ, Blanchard SG, Brown PJ, Sternbach DD, Lehmann JM, Wisely GB, Willson TM, et al. 1999 Molecular recognition of fatty acids by peroxisome proliferator-activated receptors. Molecular Cell 3 397-403. (doi:10.1016/S1097-2765(00)80467-0)

Xu J, Donepudi AC, Moscovitz JE \& Slitt AL 2013 Keap1-knockdown decreases fasting-induced fatty liver via altered lipid metabolism and decreased fatty acid mobilization from adipose tissue. PLoS One 8 e79841. (doi:10.1371/journal.pone.0079841)

Xu J, Lloyd DJ, Hale C, Stanislaus S, Chen M, Sivits G, Vonderfecht S, Hecht R, Li YS, Lindberg RA, et al. 2009b Fibroblast growth factor 21 reverses hepatic steatosis, increases energy expenditure, and improves insulin sensitivity in diet-induced obese mice. Diabetes 58 250-259. (doi:10.2337/db08-0392)

Xu J, Xiao G, Trujillo C, Chang V, Blanco L, Joseph SB, Bassilian S, Saad MF, Tontonoz P, Lee WN, et al. 2002 Peroxisome proliferator-activated receptor alpha (PPARalpha) influences substrate utilization for hepatic glucose production. Journal of Biological Chemistry 277 50237-50244. (doi:10.1074/jbc.M201208200)

Xu L, Xu C, Yu C, Miao M, Zhang X, Zhu Z, Ding X \& Li Y 2012 Association between serum growth hormone levels and nonalcoholic fatty liver disease: a cross-sectional study. PLoS One 7 e44136. (doi:10.1371/journal.pone.0044136)

Yahagi N, Shimano H, Hasegawa K, Ohashi K, Matsuzaka T, Najima Y, Sekiya M, Tomita S, Okazaki H, Tamura Y, et al. 2005 Co-ordinate activation of lipogenic enzymes in hepatocellular carcinoma. European Journal of Cancer 41 1316-1322. (doi:10.1016/j.ejca.2004.12.037)

Yamada T, Zhang SJ, Westerblad H \& Katz A 2010 \{beta\}-Hydroxybutyrate inhibits insulin-mediated glucose transport in mouse oxidative muscle. American Journal of Physiology: Endocrinology and Metabolism 299 E364-373. (doi:10.1152/ajpendo.00142.2010)

Yamauchi T, Iwai M, Kobayashi N \& Shimazu T 1998 Noradrenaline and ATP decrease the secretion of triglyceride and apoprotein B from perfused rat liver. Pflügers Archiv 435 368-374. (doi:10.1007/ s004240050525)

Yki-Jarvinen H 2016 Diagnosis of non-alcoholic fatty liver disease (NAFLD). Diabetologia 59 1104-1111. (doi:10.1007/s00125-016-3944-1)

Yoon JC, Puigserver P, Chen G, Donovan J, Wu Z, Rhee J, Adelmant G, Stafford J, Kahn CR, Granner DK, et al. 2001 Control of hepatic gluconeogenesis through the transcriptional coactivator PGC-1. Nature 413 131-138. (doi:10.1038/35093050)

You M, Matsumoto M, Pacold CM, Cho WK \& Crabb DW 2004 The role of AMP-activated protein kinase in the action of ethanol in the liver. Gastroenterology 127 1798-1808. (doi:10.1053/j.gastro.2004.09.049)

Yu XX, Lewin DA, Forrest W \& Adams SH 2002 Cold elicits the simultaneous induction of fatty acid synthesis and beta-oxidation in murine brown adipose tissue: prediction from differential gene expression and confirmation in vivo. FASEB Journal 16 155-168. (doi:10.1096/fj.01-0568com)

Zhang T, Zhao S, Li W, Ma L, Ding M, Li R \& Liu Y 2014 High-fat diet from perilla oil induces insulin resistance despite lower serum lipids and increases hepatic fatty acid oxidation in rats. Lipids in Health and Disease 13 15. (doi:10.1186/1476-511X-13-15)

Zhang W, Patil S, Chauhan B, Guo S, Powell DR, Le J, Klotsas A, Matika R, Xiao X, Franks R, et al. 2006 FoxO1 regulates multiple metabolic http://joe.endocrinology-journals.org

DOI: $10.1530 / \mathrm{JOE}-16-0513$
() 2017 Society for Endocrinology Printed in Great Britain
Published by Bioscientifica Ltd 
pathways in the liver: effects on gluconeogenic, glycolytic, and lipogenic gene expression. Journal of Biological Chemistry 281 10105-10117. (doi:10.1074/jbc.M600272200)

Zhang W, Sun Q, Zhong W, Sun X \& Zhou Z 2016 Hepatic peroxisome proliferator-activated receptor gamma signaling contributes to alcohol-induced hepatic steatosis and inflammation in mice. Alcoholism Clinical and Experimental Research Journal 40 988-999. (doi:10.1111/acer.13049)
Zhao Z, Lee YJ, Kim SK, Kim HJ, Shim WS, Ahn CW, Lee HC, Cha BS \& Ma ZA 2009 Rosiglitazone and fenofibrate improve insulin sensitivity of pre-diabetic OLETF rats by reducing malonyl-CoA levels in the liver and skeletal muscle. Life Sciences 84 688-695. (doi:10.1016/j. lfs.2009.02.021)

Zhu JZ, Dai YN, Wang YM, Zhou QY, Yu CH \& Li YM 2015 Prevalence of nonalcoholic fatty liver disease and economy. Digestive Diseases and Sciences 60 3194-3202. (doi:10.1007/s10620-015-3728-3)

Received in final form 10 April 2017

Accepted 20 April 2017

Accepted Preprint published online 20 April 2017
Published by Bioscientifica Ltd. 